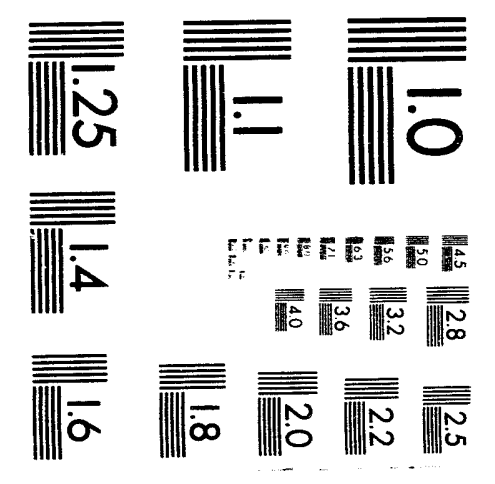



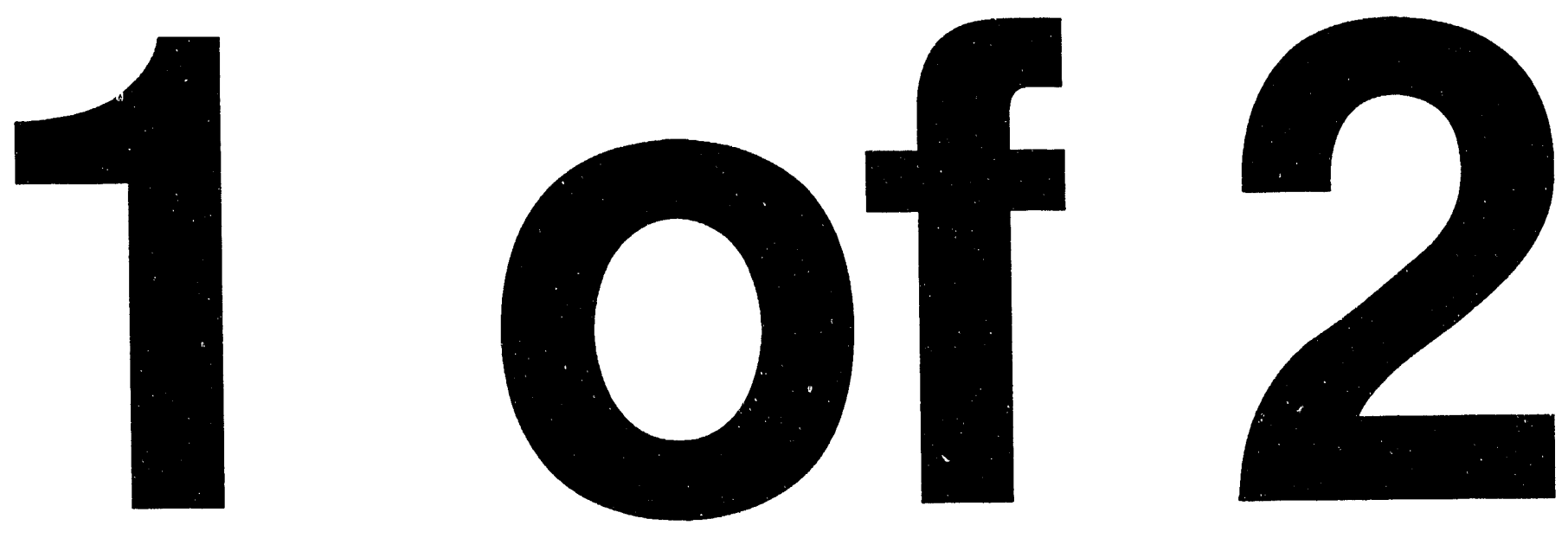
SAND93-2458

Distribution

Unlimited Release

Category UC-700

Printed March 1994

\title{
Sandia National Laboratories Interactions with Organizations in the Former Soviet Union
}

\author{
Glen H. Whiting \\ Defense Programs Sector Arms Control/ \\ Nonproliferation Special Programs \\ K. David Nokes \\ Surety Program Office \\ Sandia National Laboratories \\ Albuquerque, NM 87185-5800
}

\begin{abstract}
This document describes Sandia National Laboratories involvement with scientists and engineers at various organizations within the states of the Former Soviet Union (FSU). The purpose of these interactions is twofold: first, to acquire technical information to enhance United States technology and second, to assist FSU states in converting their defense-oriented industry to civilian, marketoriented business.
\end{abstract}

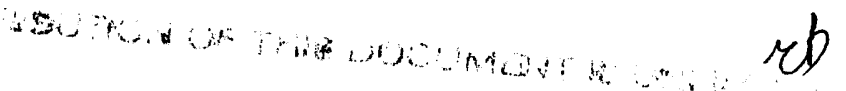


Intentionally Left Blank 


\section{Contents}

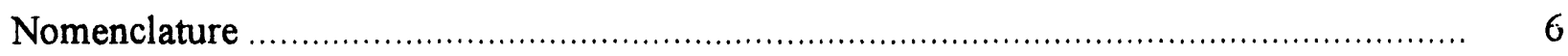

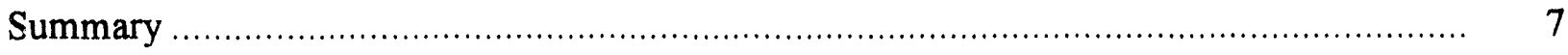

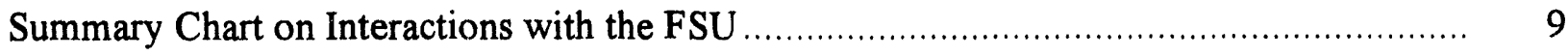

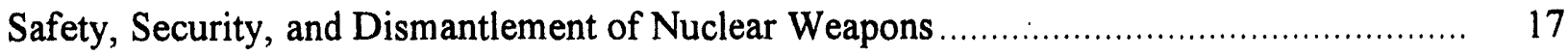

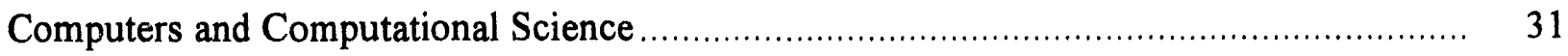

Environmental Monitoring, Characterization, and Remediation ............................ 39

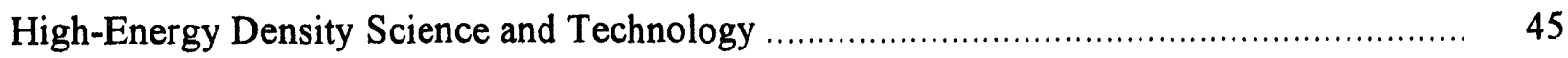

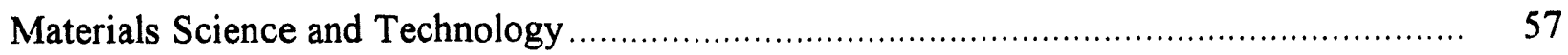

National Security, Nonproliferation, and Counter-Terrorism................................ 65 


\section{Nomenclature}

\begin{tabular}{|c|c|}
\hline $\mathrm{ABC}$ & Accelerator Based Conversion \\
\hline ATW & Accelerator Transmutation of Waste \\
\hline $\mathrm{COE}$ & Corps of Engineers \\
\hline DNA & Defense Nuclear Agency \\
\hline DoD & Department of Defense \\
\hline DOE & Department of Energy \\
\hline $\mathrm{DOE} / \mathrm{AL}$ & Department of Energy/Albuquerque Operations \\
\hline $\mathrm{DOE} / \mathrm{HQ}$ & Department of Energy Headquarters \\
\hline DP & Defense Programs \\
\hline EM & Environmental Restoration and Waste Management \\
\hline FRE & Fire-Resistant Enhancement \\
\hline FSU & Former Soviet Union \\
\hline HEU & Highly Enriched Uranium \\
\hline IS & Intelligence and Security \\
\hline ISO & International Standards Organization \\
\hline ISTC & International Science and Technology Center \\
\hline $\mathrm{KRI}$ & Khlopin Radium Institute \\
\hline LANL & Los Alamos National Laboratory \\
\hline LLNL & Lawrence Livermore National Laboratory \\
\hline MAYAK & Russian organization \\
\hline MC\&A & Material Control and Accountability \\
\hline MRO & Missouri River Office \\
\hline OPAC & Operations (Office for) Arms Control \\
\hline PIVS & Portable Integrated Video System \\
\hline POS & Plasma Opening Switch \\
\hline PRA & Probabilistic Risk Assessment \\
\hline $\mathrm{R} \& \mathrm{D}$ & Research and Development \\
\hline RHEPP & Repetitive High Energy Pulsed Power \\
\hline RPF & Rigid Polyurethane Foam \\
\hline SAB & Soft Armored Blanket Program \\
\hline SAGSTRAM & Standing Advisory Group on Safe Transport of Radioactive Materials \\
\hline SAIC & Science Applications International Corp. \\
\hline SNL & Sandia National Laboratories \\
\hline SMPC & Specialty Metals Processing Consortium \\
\hline SPC & Statistical Process Control \\
\hline SSD & Safety, Security, and Dismantlement \\
\hline TAD & Transatlantic Division \\
\hline TBD & To Be Determined \\
\hline USA & United States of America \\
\hline VO VNIPIET & Russian organization \\
\hline
\end{tabular}




\title{
Sandia National Laboratories Interactions with Organizations in the Former Soviet Union
}

\author{
Summary
}

Sandia National Laboratories (SNL) is dynamically involved in several technological activities with scientists and engineers at various laboratories and institutes within states of the Former Soviet Union (FSU). This involvement is usually directed toward the acquisition of technical information and data that will complement or enhance the technology of the United States (US). Some of these activities support the US government programs in assisting the FSU states in solving their environmental or nuclear weapon dismantlement problems.

The following summary chart and project descriptions concur with the format mutually agreed upon by Department of Energy Headquarters (DOE/HQ), Los Alamos National Laboratory (LANL), and Lawrence Livermore National Laboratory (LLNL). The summary chart provides the title of the project, the institute or institutes within the FSU, the status of the project, the DOE/HQ sponsoring organization, the funding level, and some supporting comments. The project descriptions provide more information, including the Sandia point of contact, a written summary of the project, and a written description of the current status of the project.

The information presented is usually sufficient for most inquiries; however, if additional information is required concerning any of the projects, please contact the Sandia point of contact listed in the project descriptions or call K. D. Nokes at (505) 844-3744. 
Intentionally Left Blarik 


\section{Summary Chart on Interactions with the FSU}


Intentionally Left Blank 
Summary Chart on Interactions with the FSU (Sandia National Laboratories [SNL]-Revised February 1994)

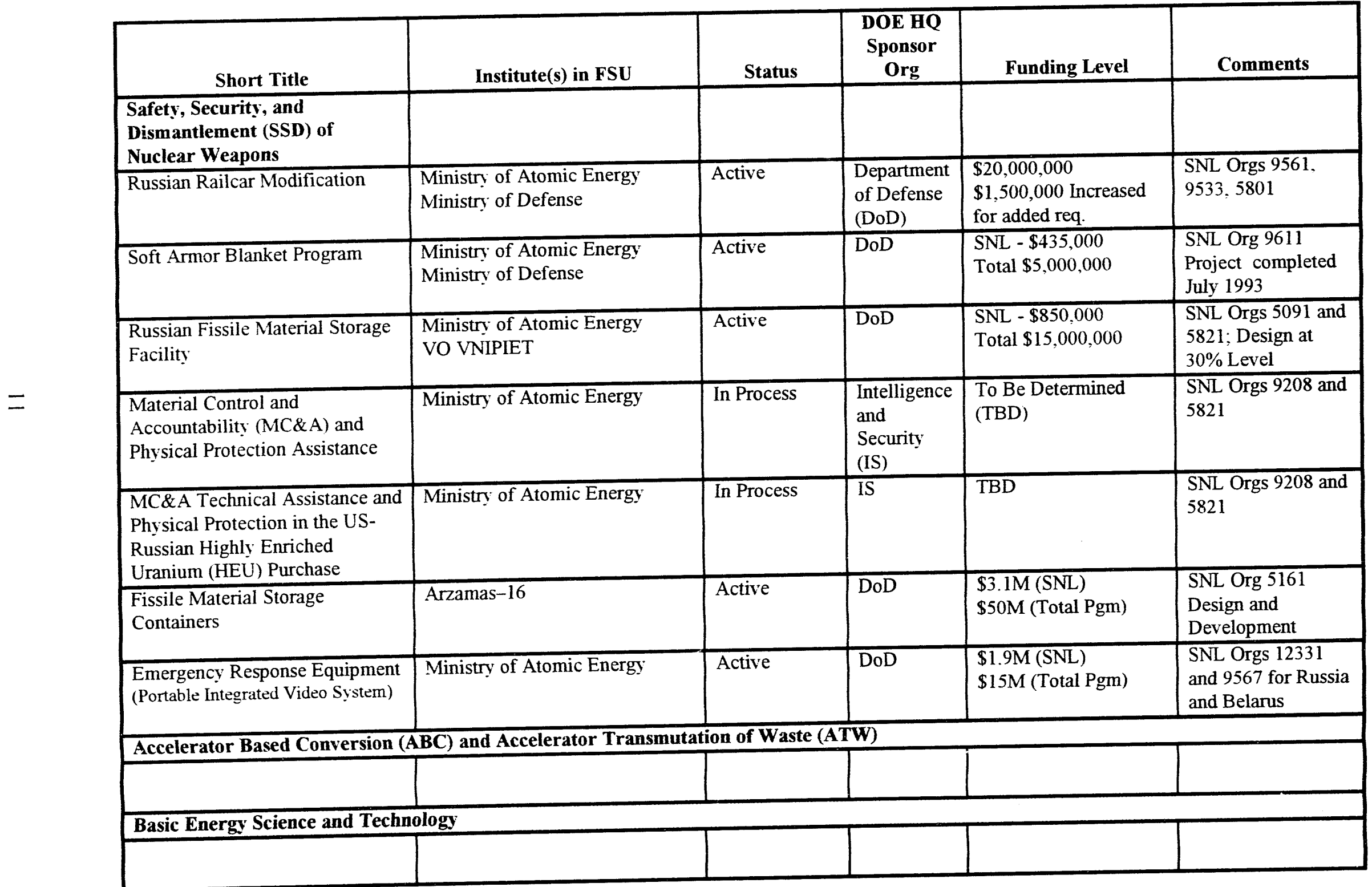




\section{Summary Chart on Interactions with the FSU, continued (Sandia National Laboratories [SNL]-Revised February 1994)}

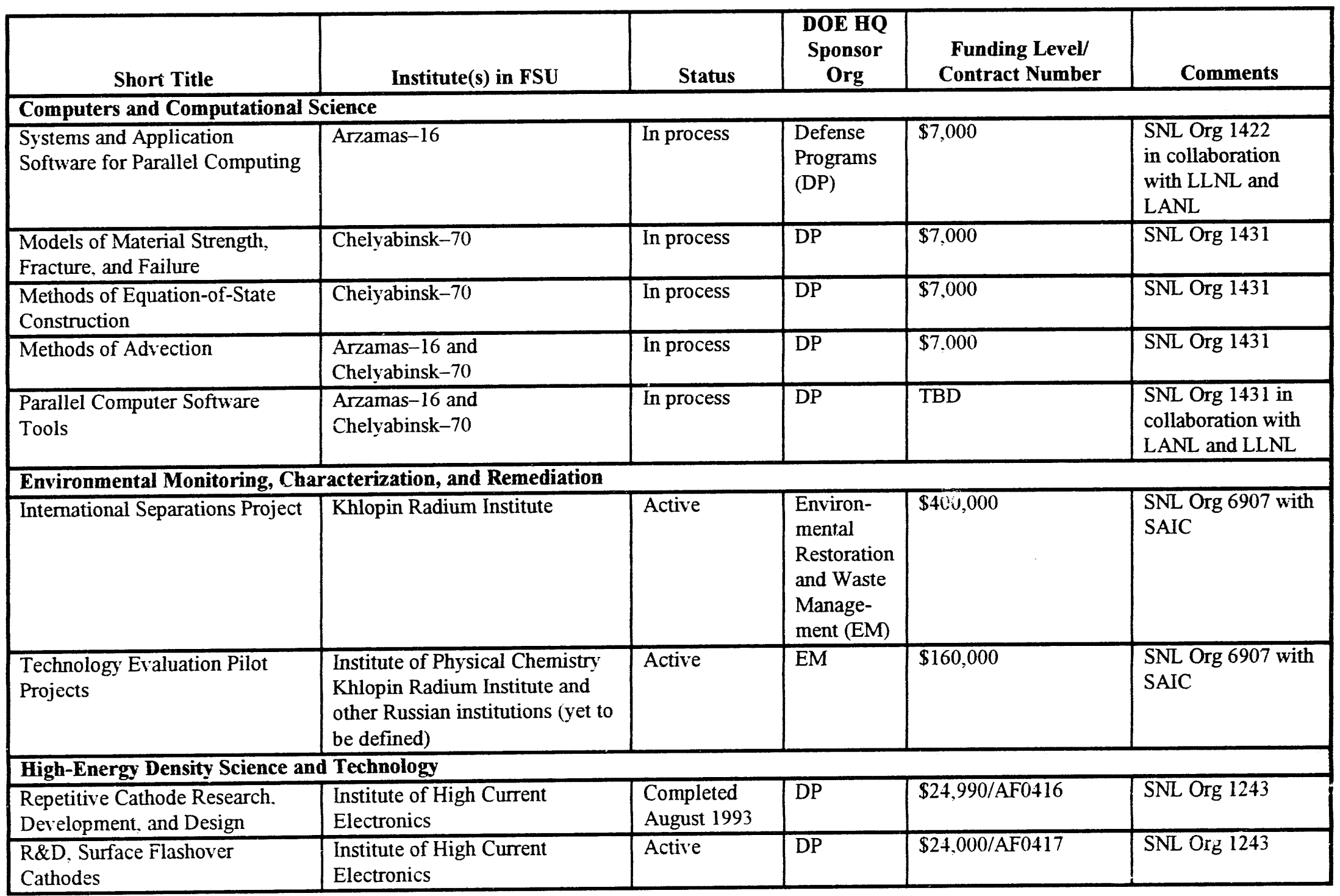


Summary Chart on Interactions with the FSU, continued (Sandia National Laboratories [SNL]-Revised February 1994)

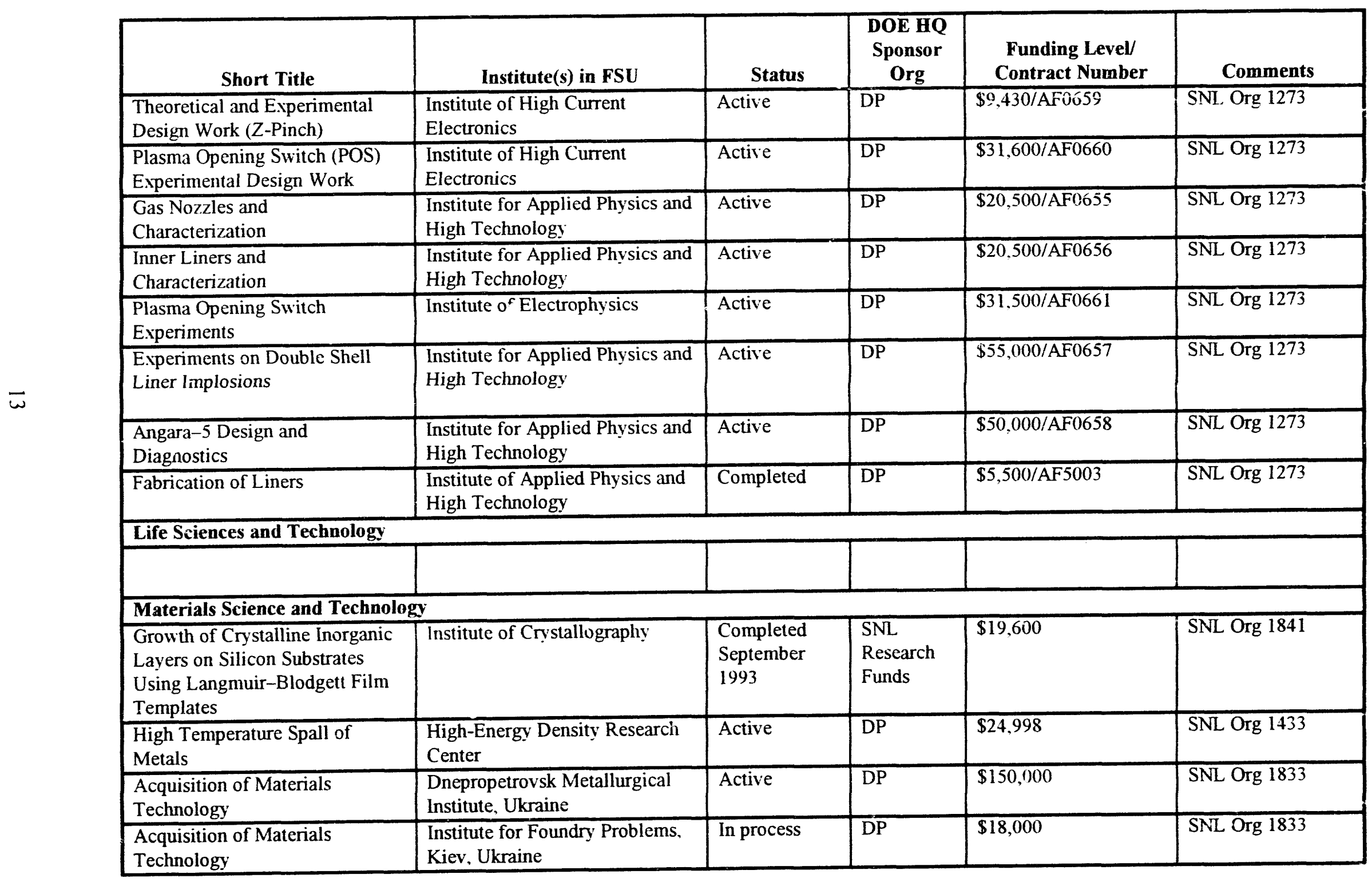


Summary Chart on Interactions with the FSU, continued (Sandia National Laboratories [SNL]—Revised February 1994)

\begin{tabular}{|c|c|c|c|c|c|}
\hline Short Title & Institute(s) in FSU & Status & $\begin{array}{l}\text { DOE HQ } \\
\text { Sponsor } \\
\text { Org } \\
\end{array}$ & Funding Level & Comments \\
\hline $\begin{array}{l}\text { Acquisition of Materials } \\
\text { Technology }\end{array}$ & Paton Institute, Ukraine & In process & $\mathrm{DP}$ & $\$ 200,000$ & SNL Org 1833 \\
\hline \multicolumn{6}{|c|}{ National Security, Nonproliferation, and Counter-Terrorism } \\
\hline $\begin{array}{l}\text { International Vibration Standard } \\
\text { for Radioactive Material } \\
\text { Packaging }\end{array}$ & VNIIEF & In Process & $\mathrm{DP}$ & $\$ 33,000$ & SNL Org 5161 \\
\hline $\begin{array}{l}\text { Small Sample Properties of } \\
\text { Adaptive Filter in Process } \\
\text { Control Applications }\end{array}$ & Arzamas-16 & In Process & DP & $\$ 11,000$ & SNL Org 12323 \\
\hline $\begin{array}{l}\text { Numerical Model to Predict } \\
\text { Organic Material Decomposition } \\
\text { and Burn Process }\end{array}$ & Arzamas-16 & In Process & DP & $\$ 21,000$ & SNL Org 1513 \\
\hline $\begin{array}{l}\text { Contamination from Accidental } \\
\text { Dispersal of Radioactive } \\
\text { Material }\end{array}$ & Chelyabinsk -70 & In Process & DP & $\$ 26,000$ & SNL Org 12333 \\
\hline $\begin{array}{l}\text { Acceptable Risk } \\
\text { Criteria-VNIITF } \\
\end{array}$ & Chelyabinsk-70 & In Process & $\mathrm{DP}$ & $\$ 25,000$ & SNL Org 6411 \\
\hline $\begin{array}{l}\text { Acceptable Risk } \\
\text { Criteria-VNIIEF } \\
\end{array}$ & Arzamas-16 & In Process & DP & $\$ 25,000$ & SNL Org 6411 \\
\hline $\begin{array}{l}\text { Data Bank Development for Risk } \\
\text { Calculations }\end{array}$ & Chelyabinsk-70 & In Process & DP & $\$ 21,000$ & SNL Org 12333 \\
\hline $\begin{array}{l}\text { Neural Networks to Process } \\
\text { Systems Response Data }\end{array}$ & Chelyabinsk-70 & In Process & $\mathrm{DF}$ & $\$ 21,000$ & SNL Org 1513 \\
\hline $\begin{array}{l}\text { Russian Probabilistic Risk } \\
\text { Assessment Methods }\end{array}$ & Chelyabinsk-70 & In Process & $\mathrm{DP}$ & $\$ 46,000$ & $\begin{array}{l}\text { SNL Orgs } 6411 \text { and } \\
12333\end{array}$ \\
\hline $\begin{array}{l}\text { Glossary of Terminology in } \\
\text { Surety Technology-VNIIEF }\end{array}$ & Arzamas-16 & In Process & DP & $\$ 12,000$ & SNL Org 509.1 \\
\hline $\begin{array}{l}\text { Glossary of Terminology in } \\
\text { Surety Technology-VNIITF }\end{array}$ & Chelyabinsk-70 & In Process & DP & $\$ 12,000$ & SNL Org 5091 \\
\hline
\end{tabular}


Summary Chart on Interactions with the FSU, continued (Sandia National Laboratories [SNL]-Revised February 1994)

\begin{tabular}{|c|c|c|c|c|c|}
\hline Short Title & Institute(s) in FSU & Status & $\begin{array}{c}\text { DOE HQ } \\
\text { Sponsor } \\
\text { Org } \\
\end{array}$ & Funding Level & Comments \\
\hline $\begin{array}{l}\text { Full-Scale and Sub-Scale } \\
\text { Aircraft Crash and Fire } \\
\text { Test-VNIIEF }\end{array}$ & Arzamas-16 & In Process & $\mathrm{DP}$ & $\$ 16,000$ & $\begin{array}{l}\text { SNL Orgs } 1513 \text { and } \\
1562\end{array}$ \\
\hline $\begin{array}{l}\text { Full-Scale and Sub-Scale } \\
\text { Aircraft Crash and Fire } \\
\text { Test-VNIITF }\end{array}$ & Chelyabinsk-70 & In Process & $\overline{\mathrm{DP}}$ & $\$ 16,000$ & $\begin{array}{l}\text { SNL Orgs } 1513 \text { and } \\
1562\end{array}$ \\
\hline $\begin{array}{l}\text { Ground Transportation Test Data } \\
\text { Documentation }\end{array}$ & Arzamas-16 & In Process & $\overline{D P}$ & $\$ 25,000$ & $\begin{array}{l}\text { SNL Orgs } 1513 \text { and } \\
12333\end{array}$ \\
\hline Actively Cooled Calorimeter & Arzamas-16 & In Process & $\overline{D P}$ & $\$ 48,000$ & SNL Org 6642 \\
\hline $\begin{array}{l}\text { Wood Impact Limiters } \\
\text { (Dampers)_VNIITF }\end{array}$ & Chelyabinsk-70 & In Process & $\overline{\mathrm{DP}}$ & $\$ 20,000$ & SNL Org 6642 \\
\hline $\begin{array}{l}\text { Wood Impact Limiters } \\
\text { (Dampers)-VNIIEF }\end{array}$ & Arzamas-16 & In Process & $\overline{\mathrm{DP}}$ & $\$ 20,000$ & SNL Org 6642 \\
\hline Penetration Technology & Chelyabinsk-70 & In Process & $\overline{\mathrm{DP}}$ & $\$ 20,000$ & $\begin{array}{l}\text { SNL Orgs } 1562 \text { and } \\
9614\end{array}$ \\
\hline $\begin{array}{l}\text { Impact Limiter Materials Aging } \\
\text { Study }\end{array}$ & Arzamas-16 & In Process & $\mathrm{DP}$ & $\$ 11.000$ & SNL Org 5161 \\
\hline $\begin{array}{l}\text { Seals Testing. Dynamic and } \\
\text { Static-VNIITF }\end{array}$ & Chelyabinsk-70 & In Process & $\overline{D P}$ & $\$ 20,000$ & SNL Org 6642 \\
\hline $\begin{array}{l}\text { Seals Testing. Dynamic and } \\
\text { Static-VNIIEF }\end{array}$ & Arzamas-16 & In Process & $\mathrm{DP}$ & $\$ 39,000$ & SNL Org 6642 \\
\hline $\begin{array}{l}\text { Safety During Rail Transport of } \\
\text { Hazardous Cargo }\end{array}$ & Chelyabinsk -70 & In Process & $\overline{\mathrm{DP}}$ & $\$ 28.000$ & $\begin{array}{l}\text { SNL Orgs } 4111 \text { and } \\
4112\end{array}$ \\
\hline $\begin{array}{l}\text { Simulations for Structural and } \\
\text { Thermal Benchmark } \\
\text { Problems-VNIITF }\end{array}$ & Chelyabinsk-70 & In Process & $\overline{\mathrm{DP}}$ & $\$ 12.000$ & $\begin{array}{l}\text { SNL Orgs } 1513 \text { and } \\
1562\end{array}$ \\
\hline $\begin{array}{l}\text { Simulations for Structural and } \\
\text { Thermal Benchmark } \\
\text { Problems-VNIIEF }\end{array}$ & Arzamas-16 & In Process & $\overline{\mathrm{DP}}$ & $\$ 12,000$ & $\begin{array}{l}\text { SNL Orgs } 1513 \text { and } \\
1562\end{array}$ \\
\hline $\begin{array}{l}\text { Temperature and Heat Flux in } \\
\text { Fires }\end{array}$ & Arzamas-16 & In Process & $\overline{D P}$ & $\$ 30,000$ & SNL Org 2761 \\
\hline
\end{tabular}


Summary Chart on Interactions with the FSU, continued (Sandia National Laboratories [SNL]-Revised February 1994)

\begin{tabular}{|l|l|l|l|l|l|}
\hline \multicolumn{1}{|c|}{ Title } & \multicolumn{1}{|c|}{ Institute(s) in FSU } & \multicolumn{1}{c|}{ Status } & $\begin{array}{c}\text { DOE HQ } \\
\text { Sponsor } \\
\text { Org }\end{array}$ & \multicolumn{1}{c|}{ Funding Level } & \multicolumn{1}{c|}{ Comments } \\
\hline $\begin{array}{l}\text { Fuel-Fire Characterization and } \\
\text { Object Response }\end{array}$ & Chelyabinsk-70 & In Process & DP & $\$ 40,000$ & $\begin{array}{l}\text { SNL Orgs 1513 and } \\
2761\end{array}$ \\
\hline $\begin{array}{l}\text { Explosion-Resistant Container } \\
\text { Development }\end{array}$ & Arzamas-16 & In Process & DP & $\$ 30,000$ & $\begin{array}{l}\text { SNL Orgs 5202 and } \\
5365\end{array}$ \\
\hline $\begin{array}{l}\text { Security Tag and Seal for Fissile } \\
\text { Material Container }\end{array}$ & Arzamas-16 & In Process & DP & $\$ 20,000$ & SNL Org 9249 \\
\hline Nuclear Reactor Safety and Radioactive Material Processing & & & & & \\
\hline & & & & & \\
\hline Space and Atmospheric Physics & & & & & \\
\hline
\end{tabular}




\section{Safety, Security, and Dismantlement of Nuclear Weapons}

The Safety, Security, and Dismantlement of Former Soviet Union nuclear weapons was identified and authorized by the Soviet Nuclear Threat Reduction Act of 1991 (Nunn-Lugar Bill). Sandia was asked to design and develop hardware under this program in those areas of Sandia expertise.. In this respect, Sandia serves our national interest in enhancing the safety and security of Russian nuclear weapons during dismantlement phases. Sandia's portion of this effort is nearly completed.

There are seven projects in this category. One (armor blankets) has been completed, one (storage facility design) is on hold, and three are active (railcar modification, emergency response equipment, and fissile material storage containers). The remaining two (material control and accountability [MC\&A] and physical protection of nuclear materials) are in negotiations at the present time. Sandia's budget for these projects is about $\$ 27 \mathrm{M}$.

No future programs are anticipated under this category. 
Intentionally Left Blank 


\section{Title:}

\section{Russian Railcar Modification}

\section{Point of Contact:}

Lyle W. Kruse, Sandia National Laboratories, 9561, Project Leader, (505) 844-6022

Donald C. Hanson, Sandia National Laboratories, 9533, Project Manager, (505) 844-4962

K. David Nokes, Sandia National Laboratories, 5801, Program Manager, (505) 844-3744

\section{Summary:}

This project will address selected steps to accomplish the modification of 100 Russian railcars and 15 Russian guard cars to assist the Russian Federation in the safeguarding of nuclear weapons in transit, in association with their eventual destruction. This requirement was identified in US-Russian official exchanges of the Safety, Security, and Dismantlement (SSD) of the Nuclear Weapons Working Group. The project comprises four phases: design, prototype, training and procurement, and support.

\section{Time Frame:}

The design phase of the project started in August 1992 during technical exchanges with the Russian team. The design was completed in early FY93, and the modification of the prototype railcar in Albuquerque began in December 1992. Prototype construction was finished in August 1993. Material required for the modification of three additional cargo cars and one guard car has been shipped to Russia. During the months of October and November 1993, the US expects to receive and inspect the kit materials and the prototype railcar at the railcar factory in Tver, Russia. The Russian modified cars are expected to be complete during early 1994. The Russian modified cars will be used along with the prototype in a joint test program during early 1994. The project is expected to be competed in FY94, and funding estimates are based upon that completion date

\section{Funding Level:}

Funding has been supplied for phases 1,2 , and 3 in the amount of $\$ 3.5 \mathrm{M}$. Funding for phase 4 has been supplied in the amount of $\$ 16.5 \mathrm{M}$ with $\$ 8.0 \mathrm{M}$ committed as of September 1993. An additional $\$ 1.5 \mathrm{M}$ will be supplied for railcar floor insulation materials to be included with each railcar kit.

\section{Institutes and Individuals Involved:}

Boris Y. Lyubovin, MINATOM, Deputy Head of Department

Vitalii Nikolaevich Yaklovlev, Ministry of Defense, Deputy Head of Administration

Andrei Borisovich Kokurin, Ministry of Defense, Section Chief

\section{Current Status:}

Phases 1, 2, and 3 have been completed. Work has begun on phase 4 . 


\section{References:}

Agreement between the DoD of the United States of America and the Ministry of the Russian Federation for Atomic Energy concerning the safe and secure transportation of nuclear weapons material through the provision of cargo and guard railcar conversion kits.

\section{Last Update:}

October 1993 


\section{Title: \\ Soft Armor Blanket Program}

\section{Point of Contact:}

Lt. Col. Gary Fowler, DNA/HQ (OPAC,SSD), (703) 325-1307

John W. Kane, Sandia National Laboratories, 9503, (505) 844-4183

Steven H. Scott, Sandia National Laboratories, 9611, (505) 845-8149

\section{Summary:}

In April 1992, Sandia hosted a series of Safety, Security, and Dismantlement (SSD) meetings in Albuquerque, New Mexico. One of those meetings was to discuss the usage of flexible armors to protect Russian nuclear weapons during the transportation and dismantlement process. The SSD delegation agreed that the United States of America would supply the Russian Republic with two types of flexible armored blankets. The first shipment occurred in the fall of 1992 and comprised approximately 200 ballistic nylon blankets. The second type of blanket was to be a Kevlar lightweight design procured by the US Government and supplied to the Russian Republic at a later date. On June 6, 1992, then-President George Bush signed an agreement with Russian President Boris Yeltsin to provide the aid previously agreed to by the SSD participants.

Funding for the Russian aid was provided by House Resolution (H.R.) 3807 (Title II), as referenced in Public Law 102-229. The appropriations were distributed to the Defense Nuclear Agency (DNA), which was also granted program manager status for the Soft Armored Blanket (SAB) program. Based upon the April 1992 work performed by Sandia, we were requested to assist DNA with blanket procurement by defining the blanket specifications, evaluation criteria, test specifications, First Article and quality assurance testing technical information for a Russian operations and maintenance manual, and producing a final project report. Additional technical exchanges were held with the Russians on December 17-18, 1992, and April 7-9, 1993.

\section{Time Frame:}

The program began in April 1992 and was completed in July 1993.

\section{Funding Level:}

Funding received to date is $\$ 435 \mathrm{~K}$. Cost-saving features implemented during the program allowed Sandia to return $\$ 84 \mathrm{~K}$ deobligated funds to DNA in August 1993.

\section{Institutes and Individuals Involved:}

German Alekseevich Smirnov, Russian Institute of Automatics

Aleksandr Vladimirovich Fagotov, Ministry of Defense

Boris Lyubovin, MINATOM

Vitalii Yakovlev, Ministry of Defense

Ivan Petrovich Bondarenko, Office of the Joint Chiefs of Staff - Russian Federation

German Alekseevich Plaksitskiy, Ministry of Atomic Energy 


\section{Current Status:}

All design and testing for the program are complete. The final project report, which is our last deliverable to DNA, was completed and provided to DNA in July 1993.

\section{References:}

Monthly progress reports dated September 1992 through May 1993, John W. Kane to DNA/HQ. Specifications for Soft Armor Blankets, prepared by SNL, August 6, 1992.

Revised First Article Test Results, Kane to Lally, February 8, 1993.

Draft version, technical information for the Russian Operations and Maintenance Manual (cover letter), Scott to Fowler, March 11, 1993.

Early Production and Pre-Russian Testing, Kane to Glowaski, March 29, 1993.

United States/Russian Joint Testing, Kane to Glowaski, April 27, 1993.

Quality Assurance Testing of Flexible Armored Blankets, Kane to Glowaski, May 27, 1993.

SNL Drawing Number R39245, Soft Armor Blanket, April 5, 1993, SNL.

Drawing Number R41468, Soft Armor Blanket, Russian version, April 6, 1993.

\section{Last Update:}

October 1993 


\section{Title:}

\section{Russian Fissile Material Storage Facility}

\section{Point of Contact:}

K. David Nokes, Sandia National Laboratories, 5091, (505) 844-3744

Douglas E. McGovern, Sandia National Laboratories, 5821, (505) 844-1542

\section{Summary:}

The US Army Corps of Engineers (COE), Transatlantic Division (TAD), has the program management responsibility for assistance to the Russians. DOE/Alouquerque Operations (AL), working with Sandia National Laboratories and Los Alamos National Laboratory, is tasked with helping the COE complete all actions required for the development of design criteria/ requirements, risk assessment, safety analysis, process flow analysis, MC\&A analysis, physical protection, thermal analysis, radiation analysis, fire protection, ventilation, and other assistance in support of the design. Attendance at meetings being conducted at various locations, including Russia, and reports of meetings are also included.

Sandia is principally responsible for providing information to the US Army COE, Missouri River Office (MRO), about physical security components and systems. In addition, Sandia acts as a design review agent. Some assistance is also being provided in material handling, based on the ongoing work Sandia is performing for the DOE dismantlement effort.

A recently added task is the design of pallet carrying equipment for periodic inventories of stored containers. This pallet will be self-contained and will carry all equipment for reading and logging identification information for the fissile material containers stored in each bay of the facility. The pallet would be carried on an automatically guided forklift. This system allows stored containers to be inventoried without personnel entering a high-radiation area.

\section{Time Frame:}

Work initiated during FY93 included the development of conceptual designs. It is anticipated that work will continue at least through completion of the design, scheduled for January 1994. Activities beyond that point will depend on US/Russian agreements regarding facility construction.

Planning for the inventory pallet design work has been completed through the second quarter of FY94, when a draft requirements document will be completed. Planning is in process that would include work through FY96.

\section{Funding Level:}

Total project funding, including all COE activities, is set at $\$ 15 \mathrm{M}$. Sandia project funding is approximately $\$ 850 \mathrm{~K}$ 
Institutes and Individuals Involved:

Gennadiy Kozko, MINATOM

Anatoly A. Rogozin, VO VNIPIET

Vladimir Yuferov, Arzamas-16

Ben Wood, Bob Schaible, US Army COE/TAD

John Trout, US Army COE/MRO

Steve Goodrum, DOE/AL

Kirk Ellard, Los Alamos National Laboratory

\section{Current Status:}

Work is in process. The design is $30 \%$ complete.

\section{References:}

COE/DOE Statements of Work; Meeting Summary Notes for mutual exchanges in Omaha (August 1992), St. Petersburg (October 1992), Albuquerque (December 1992), St. Petersburg (March 1993), Omaha (June 1992).

\section{Last Update:}

December 1993 


\title{
Title:
}

\section{Material Control and Accountability (MC\&A) and Physical Protection Assistance to FSU}

\author{
Point of Contact: \\ Dennis L. Mangan, Sandia National Laboratories, 9208, (505) 845-8710 \\ Douglas E. McGovern, Sandia National Laboratories, 5821, (505) 844-1542 \\ Gerald F. Rudolfo, Sandia National Laboratories, 5821, (505) 844-6701
}

\section{Summary:}

Under the protection of the US initiative for nuclear weapons safety, security, and dismantlement (SSD), the US Department of Energy and the US Nuclear Regulatory Commission are engaged in establishing bilateral technical assistance programs with FSU states in nuclear material safeguards. The overall objective of US assistance is to help the FSU states improve their capabilities to effectively safeguard and protect nuclear material. The assistance will be carried out under bilateral agreements for cooperation and be supported by funds authorized by Congress in the Soviet Nuclear Threat Reduction Act of 1991 and successive legislation, such as the Freedom Support Act (1992).

\section{Time Frame:}

FY93 and beyond

\section{Funding Level:}

To be determined, based on successful negotiations with the Russian counterpart.

\section{Institutes \& Individuals Involved:}

V. A. Gubanov, MINATOM

O. A. Sapunov, MINATOM

Y. G. Volodin, GOSATOMNADZOR

M. I. Moskalenko, MoD

Y. Y. Belobrov, MFA

\section{Current Status:}

An agreement has been reached between the US and Russia for a bilateral assistance program to enhance nuclear material safeguards. The US representatives have formulated a program plan for this assistance program. DOE and DNA concur with the plan, and DNA has provided \$10M to fund plan activities. The US proposed a Technical Working Group meeting for the first week of November 1993, to present the plan to the Russians and secure their concurrence. At this time, the US is awaiting a reply from the Russians. The planned program will establish a national regulatory program (including an inspection function), implementation of an information system for material accounting, technical support, and installation of MC\&A and physical protection systems at two facilities. 
Discussions with officials from Ukraine, Belarus, and Kazakhstan have been held to explore the possibilities of establishing similar safeguards enhancement programs in these countries. An agreement has been initiated with Kazakhstan, but formal approval is still pending. Discussions are proceeding with the other countries.

\section{References:}

Program Plan, September 1993; various trip reports.

\section{Last Update:}

October 1993 


\section{Title:}

\section{Material Control and Accountability (MC\&A) Technical Assistance and Physical Protection in the US-Russian Highly Enriched Uranium (HEU) Purchase}

Point of Contact:

Dennis L. Mangan, Sandia National Laboratories, 9208, (505) 845-8710

Douglas E. McGovern, Sandia National Laboratories, 5821, (505) 844-1542

Gerald F. Rudolfo, Sandia National Laboratories, 5821, (505) 844-6701

\section{Summary:}

The objective of this project is the design and development of MC\&A and physical protection systems at facilities in Russia associated with the US-Russian HEU purchase. As appropriate, assistance in implementation of such systems is also included. This work will be carried out in close cooperation with the Russians with the intent to implement transparency and access measures between the US and Russia. The facilities expected to be involved in the US-Russian HEU purchase are dismantlement, storage, conversion, and blending facilities. This project will focus on the conversion and blending facilities. It may also include the output of the dismantlement facility and then transportation to the conversion facility or facilitits, but this depends on the outcome of negotiations.

\section{Time Frame:}

FY93 and beyond

\section{Funding Level:}

To be determined, based on successful negotiations with the Russian counterpart.

Institutes and Individuals Involved:

Vladislav G. Balamoutov, MINATOM

Vitali F. Kornilov, Plant Manager

\section{Current Status:}

Proposals and draft agreements are being discussed with the Russian counterpart.

\section{References:}

Program planning documents, trip report (Moscow, May 1993)

\section{Last Update:}

October 1993 


\section{Title:}

\section{AT-400R Fissile Material Container Design Requirements, Testing, and Certification}

\section{Point of Contact:}

John A. Andersen, Sandia National Laboratories, 5161, (505) 844-0391

Robert E. Glass, Sandia National Laboratories, 5161, (505) 845-8742

\section{Summary:}

This program has resulted in the development of a package for the transportation and storage of fissile materials for the Russian nuclear weapon dismantlement program. The package must meet the requirements of the International Atomic Energy Agency as well as Russian-specific transport and storage requirements. The DNA has now contracted for a minimum of 30,000 containers, manufactured by US industry.

In addition to fulfilling the requirements of international agreements, the development of this project at Sandia provided the technological basis for the current Sandia development of a US fissile materials container at minimum additional cost.

\section{Time Frame:}

$1992-1995$

\section{Funding Level:}

\$0.5M FY 1992

$\$ 1.7 \mathrm{M}$ FY 1993

\$0.9M FY 1994

\section{Institutes and Individuals Involved:}

Maj. M. Hall, DNA

Maj. R. Nelson, FC/DNA

J. A. Andersen, SNL

R. E. Glass, SNL

P. G. Seamster, DOE

R. I. Il'kaev, Arzamas-16

B. P. Barkanov, Arzamas-16

\section{Current Status:}

Design and test requirements were agreed to between Sandia and Russia, with DOE and DNA cognizance. Development testing is to be completed in December 1993. The complete design was released to DNA and was contracted to US industry for mass production. First article manufacturing is scheduled for first quarter CY94. Compliance testing is to be accomplished early in CY94. Container shipments to Russia are scheduled to begin mid-1994. 
References:

AT-400R Requirements Document, August 1993; AT-400R Test Plans, August 1993.

\section{Last Update:}

December 1993 


\section{Title:}

\section{Emergency Response Equipment (Portable Integrated Video System)}

\section{Point of Contact:}

Stanley D. Spray, Sandia National Laboratories, 12331, (505) 844-3135

David Shirey, Sandia National Laboratories, 9567, (505) 844-9790

\section{Summary:}

The Defense Nuclear Agency, working through DOE/AL, has the responsibility to provide emergency response equipment to the Former Soviet Union. To support this objective, the Sandia-New Mexico facility will provide four sets of equipment that constitute the Portable Integrated Video System (PIVS). PIVS was designed and developed at Sandia in support of the Accident Response Group activities. In addition to the hardware, Sandia has produced an operator's manual and a training manual and has conducted at the Albuquerque facility preliminary training sessions. A final training session will be held in Moscow from October 25 through November 5, 1993.

\section{Time Frame:}

Work was initiated in FY93 and is scheduled for completion during FY94.

\section{Funding Level:}

$\$ 1,817 \mathrm{M}$.

Institutes and Individuals Involved:

German Plaksitskiy, MINATOM

COL M. K. Evenson, HQDNA

Dr. James M. Turner, HQDOE

Stuart V. Rogers, DOE/AL

\section{Current Status:}

All four PIVS units, as well as associated spares and expendables, were procured, built, and shipped by October 15, 1993. Training in Russia will take place October 25 through November 5. A follow-up training session is projected for the summer of 1994 .

\section{Last Update:}

October 1993 


\section{Computers and Computational Science}

Sandia has teamed with Los Alamos and Lawrence Livermore National Laboratories in the area of computers and computational science. It is Sandia's objective to identify those "centers of excellence" in the Former Soviet Union (FSU) computer and computational science fields and enter into collaborations with those institutes and/or individuals. Russian researchers, for example, have valuable, practical experience in applying parallel computer processing to a wide variety of mathematical computational problems, and the national laboratories and US industry have a very high, immediate interest in applying this technology here in the US. Similarly, Russian researchers have had extensive experience in developing advection methods and constructing equations of state. Four contracts, for a total of $\$ 28 \mathrm{~K}$, are in place for the Russians to provide reports and guidance in these selected areas.

It is Sandia's intent to continue to search out additional centers of excellence and work with the FSU researchers to obtain and understand the computational methods they use. 
Intentionally Left Blank 


\section{Title: Systems and Application Software for Parallel Computing}

\section{Point of Contact:}

Bruce Hendrickson, Sandia National Laboratories, 1422, (505) 845-7599

Harold Trease, Los Alamos National Laboratory

Randy Christensen, Lawrence Livermore National Laboratory

\section{Summary:}

The national laboratories and US industry have an immediate interest in applying parallel processing to a wide variety of problems in mathematical computation. Russian researchers have valuable, practical experience in this area that would be of immediate benefit.

Russian researchers will prepare several reports of their accomplishments in the area of parallel processing that have not been generally available to their US counterparts. They will report the results of work on three tasks:

- Strategy for parallellization of calculation of the diffusion equation as exemplified by the Ramzes methodology and the Mimosa methodology.

- Strategy of parallel implementation of the Medusa methodology; clusterization of data and dynamic load balancing.

- Requirements of software to test communication characteristics of multiprocessors.

Time Frame:

To be determined

Funding Level:

$\$ 7 \mathrm{~K}$

Institutes and Individuals Involved:

V. Gribov and I. Sofronov, Arzamas-16

Current Status:

In negotiation

References:

None

Last Update:

October 1993 


\section{Title:}

\section{Models of Material Strength, Fracture, and Failure}

\section{Point of Contact:}

Michael McGlaun, Sandia National Laboratories, 1431, (505) 845-8236

Thomas Adams, Los Alamos National Laboratory

Don Burton, Los Alamos National Laboratory

\section{Summary:}

Dynamic processes involving solids are dominated by material strength effects, such as plastic yielding and fracture. To treat these effects in advanced computer codes requires three tasks

(1) development of theoretical models, (2) the implementation of these models in numerical algorithms, and (3) determination of material constants from experimental data. The basic code algorithms should have sufficient accuracy in order to prevent the introduction of spurious numerical effects.

Researchers at VNIITF (Chelyabinsk-70) have developed advanced material models including fracture. They have applied these models in codes to predict rock breakage and ground shock propagation resulting from contained underground nuclear explosions. The predictions are apparently in agreement with the results of the experiments.

\section{Time Frame:}

To be determined

\section{Funding Level:}

$\$ 7 \mathrm{~K}$

Institutes and Individuals Involved:

Valentin Kouropatenko and Vladimir Bichenkov, Chelyabinsk-70

\section{Current Status:}

In negotiation

\section{References:}

None

Last Update:

October 1993 


\section{Title:}

\section{Methods of Equation-of-State Construction}

\section{Point of Contact:}

Michael McGlaun, Sandia National Laboratories, 1431, (505) 845-8236

George Zimmerman, Lawrence Livermore National Laboratory

Richard More, Lawrence Livermore National Laboratory

\section{Summary:}

Equation-of-state questions are of mutual interest to the nuclear centers of both Russia and the US. Historically, a great deal of difficulty has existed in merging various equation-of-state theories and experimental data in a manner that preserves thermodynamic consistency.

This contract will introduce American scientists to the current state of expertise on methods of construction equations-of-state in Russian nuclear centers. We will then meet with Russian counterparts to discuss further collaboration in this area.

\section{Time Frame:}

To be determined

\section{Funding Level:}

$\$ 7 \mathrm{~K}$

Institutes and Individuals Involved:

Valentin Kouropatenko and A. Sapozhnikova, Chelyabinsk-70

\section{Current Status:}

In negotiation

\section{References:}

None

\section{Last Update:}

October 1993 


\section{Title:}

\section{Methods of Advection}

\section{Point of Contact:}

Michael McGlaun, Sandia National Laboratories, 1431, (505) 845-8236

Doug Kothe, Los Alamos National Laboratory

Randy Christensen, Lawrence Livermore National Laboratory

\section{Summary:}

Many key application areas of interest to industry involve multidimensional flows with large deformations. Russian researchers have had extensive experience in developing the advection methods used to address this type of flow in numerical simulation codes.

Reports, including examples from existing codes, will be generated that describe Russian research and accomplishments in this important algorithmic area.

\section{Time Frame:}

To be determined

\section{Funding Level:}

$\$ 7 \mathrm{~K}$

\section{Institutes and Individuals Involved:}

Lyudmila Nesterenko, Arzamas-16

Valentin Kouropatenko, Chelyabinsk-70

\section{Current Status:}

In negotiation

References:

None

Last Update:

October 1993 


\section{Title:}

\section{Parallel Computer Software Tools}

\section{Point of Contact:}

Mike McGlaun, Sandia National Laboratories, 1431, (505) 845-8236

Rick Wallace, Los Alamos National Laboratory, X-DO (B218), (505)-667-7681

Dave Nowak, Lawrence Livermore National Laboratory

\section{Summary:}

Parallel computers hold the promise of providing orders of magnitude improvements in memory size and processing speed. Software tools are needed to make it easier to program parallel computers. This project will fund development, analysis, and debugging tools for parallel software development, nonprocedural languages, file management, post-processing, and applications.

This work, to be performed by scientists at Arzamas-16 and Chelyabinsk-70, will develop tools for developing, maintaining, and using parallel computers

\section{Time Frame:}

Three years from time of start. Expected start is FY94.

\section{Funding Level:}

To be determined

\section{Institutes and Individuals Involved:}

I. D. Sofronov, Arzamas-16

V.F. Kuropatenko, Chelyabinsk-70

\section{Current Status:}

In discussion

\section{References:}

This project is based on a proposal given to SNL at the Second Joint Conference on Computational Mathematics held at Arzamas-16, September 6 through 11, 1993.

\section{I ast Update:}

December 1993 
Intentionally Left Blank 


\section{Environmental Monitoring, Characterization, and Remediation}

Many environmental releases of radioactive and hazardous chemicals have occurred over the past forty years at the Mayak complex, which was the major site of nuclear weapon production in the Former Soviet Union. The US nuclear weapon complex shares this experience, although to a lesser degree. This situation poses immediate and long-range risks to the population of Russia and the rest of the world through potential direct exposure as well as through groundwater and surface-water discharge to the Arctic Ocean. With similar situations existing in both the US and Russia, a unique opportunity exists for cooperation on environmental restoration of the environment. Sandia prọects will assess the degree of damage, use existing technologies to start the restoration process, develop technologies where needed, using FSU scientists, and establish demonstration projects.

To date, Sandia has two environmentally related contracts with the FSU for a sum of $\$ 560 \mathrm{~K}$. Over thirty additional projects have been identified for future implementation, which are limited at the present time by the lack of funds. 
Intentionally Left Blank 


\section{Title:}

\section{International Separations Project}

\section{Point of Contact:}

Ken Bergeron, Sandia National Laboratories, Program Manager, 6907, (505) 844-2507

Thomas E. Albert, SAIC, Vice President, (813) 530-4000

\section{Summary:}

Reprocessing of high-level defense wastes stored in tanks is an urgent problem for both the US and Russia. The need for reprocessing and ultimate disposal of accumulated wastes is exacerbated by the hazard of long-term storage of liquid high-level waste. The nature of the hazard is the potential release of radioactivity into the environment. Such a situation could arise if the storage facilities suffered damage as a result of either a natural catastrophe or aging. It is also expedient to reprocess high-level waste stored in tanks because of the potential economic benefits resulting from reduced quantities of vitrified wastes

A contract involving a previously unknown Russian separations technology (cobalt dicarbollide) was established between SNL, SAIC, and the Khlopin Radium Institute (KRI) in the summer of 1992. The work, specifically directed to the treatment of Hanford wastes, was completed successfully in September 1992

The work now under way has been broadened in scope. It now includes investigation of the feasibility of using this method of treatment on a variety of US radioactive wastes, including Hanford, Idaho, and Savannah River. Special emphasis has been placed on the Idaho waste forms. The KRI will perform laboratory testing and dynamic hot cell testing using Russian technology on simulated uranium radioactive wastes over a 12-month period. Overall feasibility of the Russian technology by the KRI will occur over a period of 2 to 3 years to determine its viability for use on actual US radioactive wastes.

\section{Time Frame:}

The project began as a pilot project in August 1992. Following successful completion of the pilot phase, the project was transitioned in March 1993 to a more in-depth study to determine the feasibility of using the cobalt dicarbollide project in treatment of various DOE tank wastes.

\section{Funding Level:}

\$400K (FY94)

\section{Institutes and Individuals Involved:}

Valeriy Romanovskii, Khlopin Radium Institutes, St. Petersburg and Gatchina, Russia Minatom Production Association MAYAK 


\section{Current Status:}

All work is on schedule and proceeding in accordance with the contract. Dynamic tests involving the simulated Idaho waste samples are now under way. DOE and laboratory personnel conducted a thorough review of the status early in August 1993.

\section{References:}

Sandia National Laboratories Purchase Order No. 874331

Report on the Project Applicability of the Russian Separation Technology to Reprocessing of the USA Radioactive Wastes, V.G. Khlopin Radium Institute

\section{Last Update:}

December 1993 


\title{
Title:
}

\section{Technology Evaluation Pilot Projects}

\section{Point of Contact:}

Ken Bergeron, Sandia National Laboratories, Program Manager, 6907,(505) 844-2507

Thomas E. Albert, SAIC, Vice President, (813) 530-4000

\begin{abstract}
Summary:
A strategy was developed in FY92 to make more cost-effective use of Russian capabilities for the identification and initial evaluation of candidate technology transfer projects. The approach was to establish a small pilot technology project with an appropriate Russian institute and use Russian scientists to evaluate the potential applicability of an identified technology to DOE/EM technology requirements. The first of these pilot projects involved Russian separations technologies and was established among SNL, SAIC, and the Khlopin Radium Institute (KRI) in the summer of 1992. The work, directed toward the application of the cobalt dicarbollide process to the treatment of Hanford waste, was completed successfully in September 1992. Based on the initial success of this approach, an expanded pilot technology evaluation program has been authorized for FY93 carrying into FY94.
\end{abstract}

The four principal benefits of the pilot technology evaluation projects as one approach for technology identification and screening are

- Provides leverage for the equivalent of billions of dollars invested by the Former Soviet Union over the past 40 years in independent research in environmental remediation and waste management technologies

- Takes advantage of cost-effective Russian labor rates for initial technology screening

- Provides direct access to Russian technology; minimizes risk by providing an opportunity to evaluate the capabilities and credentials of key Russian scientists and institutes before making commitments for more significant technology demonstration projects

- Contributes toward US objectives to assist in the stabilization and conversion of the nuclear industry in the Former Soviet Union

\section{Time Frame:}

The project began as a pilot project in August 1992. Following successful completion of the pilot phase, the program was transitioned in March 1993 to a more in-depth feasibility study to assess whether the cobalt dicarbollide process could be used in treating various DOE tank wastes.

\section{Funding Level:}

\$160K (FY94) 


\section{Institutes and Individuals Involved:}

Alexander A. Rimski-Korsakov, Khlopin Radium Institute

Vladimir M. Gelis, Institute of Physical Chemistry

Evgeniy G. Grozhko, MAYAK Production Association and Institute of Chemistry Technology

Other institutes yet to be identified

\section{Current Status:}

All work is on schedule and proceeding in accordance with the contract. The thrust for FY94 will encompass initiating up to eight (8), but not less than four (4), new pilot technology evaluation projects involving Russian ER and WM technologies that have high probability of application in the DOE complex cleanup activities. Each pilot project will be modest in cost (up to about $\$ 10 \mathrm{~K}$ per project) and will provide an initial assessment of technology status, suitability, and risk associated with possible use at the DOE sites. In addition, SNL is providing powerful workstations on loan to Russian institutes to run such analysis programs as EnviroTRADE for the EM program.

\section{References:}

Sandia National Laboratories Purchase Order No. 87-4331

\section{Last Update:}

December 1993 


\section{High-Energy Density Science and Technology}

Former Soviet Union pulsed power technology appears to be more advanced than that of the US in areas such as the production of high-temperature foams, magnetized fusion targets, repetitively pulsed Tesla generators, multiple plasma opening switch devices, and long-lifetime, repetitive, surface-flashover cathodes. Sandia has identified several leading scientists in these areas and has placed several contracts in an attempt to advance US programs in inertial confinement fusion testing and R\&D. Several contracts have been completed on repetitive cathode research, history of the theoretical and experimental work on the stabilized Z-pinch implosions, development of gas nozzles, development of low-density inner liners, and experiments on inner-liner implosions. Research programs have been initiated to advance this technology to an even higher level. Total funding for these contracts is $\$ 327 \mathrm{~K}$.

It is very probable that Sandia has identified only a small percentage of the pulsed power technology available in the FSU. We will continue to search for additional technology that can enhance our US program. 
Intentionally Left Blank 


\section{Title: \\ Repetitive Cathode Research, Development, and Design; Surface Flashover Cathodes}

\section{Contacts:}

David L. Johnson, Sandia National Laboratories, 1243, (505) 845-7118

Eugene L. Neau, Sandia National Laboratories, 1243, (505) 845-7120

\section{Summary:}

Two contracts have been placed with the High Current Electronics Institute, Tomsk, Russia, to provide research on long-lifetime, repetitive, surface-flashover cathodes for the RHEPP (Repetitive High Energy Pulsed Power) Program. Each of the two contracts provides three deliverables. The first contract, AF-0416, provides: (1) a report, based on a literature search, on surface-flashover cathodes; (2) experimental data on the performance and lifetime of a rep-rate surface-flashover cathode; and (3) a preliminary design of a cathode for the 2.5 MV RHEPP accelerator. The second contract, AF-0417, provides: (1) the detailed design and drawings of the 2.5 MV cathode; (2) delivery of the cathode to Sandia; and (3) a follow-up report of analysis of the cathode performance based on data from the RHEPP accelerator.

Time Frame:

AF-0416 Completed August 15, 1993

AF-0417 Estimated completion May 1, 1994

\section{Funding:}

AF-0416 \$24,990

AF-0417 \$24K

Institutes and Individuals Involved:

Current: Sergei D. Korovin, High Current Electronics Institute

\section{Status:}

Sandia has received the final report for AF-0416. Sandia will approve the start of the second contract pending the outcome of a design review at Tomsk in November 1993. 


\section{Title:}

\section{Theoretical and Experimental Design Work (Z-Pinch)}

\section{Point of Contact:}

Dillon H. McDaniel, Sandia National Laboratories, 1273, (505) 845-7494

Summary:

The object of this program is to develop a detailed history of the theoretical and experimental results of the work performed on the stabilized Z-Pinch implosions.

Time Frame:

Through December 1993

Funding Level:

$\$ 9,430$

Institutes and Individuals Involved:

Andre V. Luchinsky, Institute of High Current Electronics

Current Status:

In process

\section{References:}

None

\section{Last Update:}

February 1994 


\section{Title:}

\section{Plasma Opening Switch (POS) Experimental Design W'ork}

\section{Point of Contact:}

Dillon H. McDaniel, Sandia National Laboratories, 1273, (505) 845-7494

\section{Summary:}

The object of this program is to establish a research program with the Institute of High Current Electronics in cooperation with the institute of Electrophysics. The program will investigate the scaling of SNL's Plasma Opening Switch.

\section{Time Frame:}

Through January 1995

\section{Funding Level:}

$\$ 31,600$

Institutes and Individuals Involved:

Boris Kaval Chuk, Institute of High Current Electronics

\section{Current Status:}

In process

References:

None

\section{Last Update:}

February 1994 


\section{Title:}

\section{Gas Nozzles and Characterization}

Point of Contact:

Dillon H. McDaniel, Sandia National Laboratories, 1273, (505) 845-7494

\section{Summary:}

The object of this program is to develop Xe and Ar gas nozzles for use on the Saturn accelerator The program will define elements to optimize the production of radiation energy density for applications to $\mathrm{x}$-ray laser research at SNL.

Time Frame:

Through 1993

Funding Level:

$\$ 20,500$

Institutes and Individuals Involved:

Andre V Luchinsky, Institute for Applied Physics and High Technology

Current Status:

In process

References:

None

Last Update:

February 1994 


\section{Title:}

\section{Inner Liners and Characterization}

\section{Point of Contact:}

Dillon H. McDaniel, Sandia National Laboratories, 1273, (505) 845-7494

\section{Summary:}

The object of this program is to develop low-density inner liners for use on the Saturn accelerator. The program will define elements to optimize the production of radiation energy density for applications to $x$-ray laser research at SNL.

Time Frame:

Through 1993

Funding Level:

$\$ 20,500$

Institutes and Individuals Involved:

Andre V. Luchinsky, Institute of Applied Physics and High Technology

Current Status:

In process

\section{References:}

None

Last Update:

February 1994 


\section{Title:}

\section{Plasma Opening Switch (POS) Experiments}

\section{Point of Contact:}

Dillon H. McDaniel, Sandia National Laboratories, 1273, (505) 845-7494

\section{Summary:}

The purpose of this project is to establish a research program with the Institute of Electrophysics in cooperation with Institute of High Current Electronics. The program will investigate the scaling of SNL's Plasma Opening Switch (POS).

Time Frame:

Through February 1995

Funding Level:

$\$ 31,500$

Institutes and Individuals Involved:

V. Vystritskii, Institute of Electrophysics

\section{Current Status:}

In process

\section{References:}

None

Last Update:

February 1994 


\section{Title:}

\section{Experiments on Double Shell Liner Implosions}

\section{Point of Contact:}

Dillon H. McDaniel, Sandia National Laboratories, 1273, (505) 845-7494

\section{Summary:}

The purpose of this project is to establish a research program through the International Institute for Applied Physics and High Technology to be led by the Angara research team at the Triniti Institute. The program will provide for a series of experiments at the Angara-5 accelerator to verify the recent results on double shell liner implosions.

\section{$\because$ Time Frame:}

Through May 1994

\section{Funding Level:}

$\$ 55,000$

Institutes and Individuals Involved:

V. P. Snirnor and V. Tsaifin, Institute for Applied Physics and High Technology

\section{Current Status:}

In process

\section{References:}

None

Last Update:

February 1994 


\section{Title:}

\section{Angara-5 Design and Diagnostics}

\section{Point of Contact:}

Dillon H. McDaniel, Sandia National Laboratories, 1273, (505) 845-7494

\section{Summary:}

The purpose of this project is to establish a research program through the International Institute for Applied Physics and High Technology to be led by the Angara research team at the Triniti Institute, Traitsk, Russia. The program will provide for a series of experiments at the Angara-5 facility and support for the diagnostics from the US team

Time Frame:

Through May 1994

Funding Level:

$\$ 50,000$

Institutes and Individuals Involved:

V P. Smirnor, Institute of Applied Physics and High Technology

Current Status:

In process

\section{References:}

None

\section{Last Update:}

February 1994 


\section{Title:}

\section{Fabrication of Liners}

Point of Contact:

Dillon H. McDaniel, Sandia National Laboratories, 1273, (505) 845-7494

Summary:

The purpose of this project is to purchase inner liners to be used and expended in Russia during tests.

Time Frame:

Through June 1993

Funding Level:

$\$ 5,500$

Institutes and Ind viduals Involved:

Institute of Applied Physics and High Technology

Current Status:

Completed

References:

None

Last Update:

February 1994 


\section{Intentionally Left Blank}




\section{Materials Science and Technology}

Former Soviet Union (FSU) scientists in the Ukraine and Russia have developed unique technologies that, along with others yet to be identified, can enhance our US materials programs. Examples include high-quality electro-optic crystalline films, specialized high-resolution shockwave data, porous metal technology, micro-structural characterization of hyper-eutectic alloys, high-temperature measuring technology, and high-powered gyrotron microwave generator technology. At Sandia, these technologies could greatly aid the specialty metals processing consortium (SMPC) program. To date, total funding for this category is $\$ 399 \mathrm{~K}$.

Sandia believes that much exiremely useful materials technology exists in the Former Soviet Union and will continue to explore various sources, including FSU scientific institutes, in an effort to identify additional technology. 
Intentionally Left Blank 


\title{
Title:
}

\section{Growth of Crystalline Inorganic Layers on Silicon Substrates Using Langmuir-Blodgett Film Templates}

\author{
Point of Contact: \\ Joseph Cesarano, Sandia National Laboratories, 1841, (505) 272-7624 \\ Alan J. Hurd, Sandia National Laboratories, 1841, (505) 845-8629
}

\section{Summary:}

This project attempts to develop a new technique to nucleate and grow oriented crystalline electro-optic materials on silicon substrates for possible microelectronics or sensor applications. The technique attempts to use two-dimensional crystalline Langmuir-Blodgett films to act as templates for the controlled growth of crystalline ceramic films. Essentially, experimentalists are trying to use organized organic molecules to control the growth of inorganic crystals much in the same way that bones grow in animals. If successful, the project will provide very high quality electro-optic crystalline films which may benefit the US microelectronics industry.

The success of the project depends primarily on two difficult tasks: (1) Langmuir-Blodgett film technology; and (2) characterization of the film structures using $x$-ray and neutron reflectivity and electron diffraction.

\section{Time Frame:}

The program began in January 1993 and was completed on September 15, 1993. Sandia would like to continue this collaboration and is searching for resources to do so.

\section{Funding Level:}

Sandia Organization 1841 allocated $\$ 20 \mathrm{~K}$ for the period from January through September 1993.

\section{Institutes and Individuals Involved:}

Professor Lev A. Feign, Institute of Crystallography, Russian Academy of Science, Moscow, Russia

\section{Current Status:}

This project is approximately $75 \%$ completed. The work has been very well done and the results are promising. Films have been fabricated and preliminary characterization analysis is being completed.

\section{References:}

Sandia Contract \# AE-3528

\section{Last Update:}

October 1993 


\section{Title: \\ High Temperature Spall of Metals}

Point of Contact:

Dennis E. Grady, Sandia National Laboratories, 1433, phone (505) 844-2799; fax (505) 844-0918

Phillip L. Stanton, Sandia National Laboratories, 1433, phone (505) 845-8439;

fax (505) 844-0918

\section{Summary:}

As of April 12, 1993, a contract is in place with the Shock Physics Laboratory of the HighEnergy Density Research Center in Moscow, Russia, to provide high-temperature and ultra-high strain rate shock-wave spall and fragmentation measurements on selected metals. This laboratory has unique capabilities for acquiring the necessary specialized high-resolution shock-wave data and an impressive history of providing such data. Sandia National Laboratories has a need for high-quality fracture and fragmentation data on special metals over an expanded range of thermomechanical states of matter, and particularly in the high-temperature solid and liquid state toward which this program is focused. Sandia programs that will benefit from this data include: (1) soft $\mathrm{x}$-ray lithography research in which laser blow-off fragment debris represents a critical problem area; (2) nuclear weapon safety issues concerning nonnuclear dispersal of component materials; and (3) hypervelocity impact and bumper shield design of space assets.

\section{Time Frame:}

The program was organized for 9 months from start of contract. Follow-on efforts will be warranted if the initial study is successful.

\section{Funding Level:}

Funding of $\$ 25 \mathrm{~K}$ was provided by Sandia for the 9-month study.

\section{Institutes and Individuals Involved:}

G. I. Kanel, V. E. Fortov, A. V. Utkin, S.V. Razorenov, A. Z. Zhuk, High-Energy Density Research Center, Moscow

\section{Current Status:}

Funds have been transferred to the High-Energy Density Institute in payment for completion of Tasks 1, 2, and 3 of this five-task program. The investigators are continuing to work on the focal effort of the program, which is to provide critical experimental data on the dynamic spall properties of selected metals in the high-temperature solid and liquid state. This effort is proceeding without significant difficulties, and researchers indicate that program work is on schedule. 


\section{References:}

Task 1-Program research plan, May 1993.

Task 2-Tin and lead samples for high-temperature spall measurements, July 1993.

Task 3-Elevated temperature spall data on selected metals, September 1993.

(Available from Sandia point of contact.)

\section{Last Update:}

December 1993 


\section{Title:}

\section{Acquisition of Materials Technology from the Dnepropetrovsk Metallurgical Institute in Dnepropetrovsk, Ukraine}

\section{Point of Contact:}

Frank J. Zanner, Sandia National Laboratories, 1833, (505) 845-3085

\section{Summary:}

Three projects will be contracted with at the Dnepropetrovsk Metallurgical Institute:

(1) acquisition of porous metals technology; (2) development of pseudo-binary-phase diagrams for alloy 718 varying $\mathrm{Nb}$ and $\mathrm{Ti}$ at the expense of $\mathrm{Cr}$; and (3) microstructural characterization of Al-Si hyper-eutectic alloys. The porous metal project will involve laboratory work in the Ukraine and the transfer of this technology to Sandia. The other projects are strictly research contracts to be conducted at the institute.

\section{Time Frame:}

The schedule for completing all of the above projects is 2 years from the time that orders are placed.

\section{Funding Level:}

Expenditures of $\$ 80 \mathrm{~K}$ for porous metals; $\$ 52 \mathrm{~K}$ for alloy 718 ; and $\$ 20 \mathrm{~K}$ for Al-Si alloys are planned.

\section{Institutes and Individuals Involved:}

Dnepropetrovsk Institute for this work; Vladimir Shapovalov for the porous metals; Polina Nizhnikovskaja for alloy 718; and Jurij Taran for Al-Si.

\section{Current Status:}

The contract on porous metals was placed in July 1993. Technical details have been worked out for the other projects, and contracts are under negotiation.

\section{References:}

All of these Ukrainian investigators are internationally known in these fields of work.

\section{Last Update:}

October 1993 


\section{Title:}

\section{Acquisition of Materials Technology from the Institute for Foundry Problems in Kiev, Ukraine}

\section{Point of Contact:}

Frank J. Zanner, Sandia National Laboratories, 1833, (505) 845-3085

\section{Summary:}

This Institute for Foundry Problems has developed a novel temperature measurement technology which consists of a sapphire window passing through the refractory of a furnace lining and the measurement of transmitted light with an optical pyrometer.

\section{Time Frame:}

Contract duration is 1 year from the time that the order is placed.

\section{Funding Level:}

Expenditures of $\$ 18 \mathrm{~K}$ for one unit and four sapphire windows are planned.

Institutes and Individuals Involved:

Segri Zatulovsky, Institute for Foundry Problems

\section{Current Status:}

Technical details have been completed, and the contract is under negotiation.

\section{References:}

None

Last Update:

October 1993 


\section{Title:}

\section{Acquisition of Materials Technology from the Paton Institute in Kiev, Ukraine}

\section{Point of Contact:}

Frank J. Zanner, Sandia National Laboratories, 1833, (505) 845-3085

\section{Summary:}

A $35-\mathrm{kW}, 3-\mathrm{mm}$ wavelength gyrotron microwave generator will be purchased from the Paton Institute in Kiev. The services of a Paton technical person will also be contracted to provide operational assistance at Sandia. This microwave generator will be used for a proprietary specialty metals processing consortium (SMPC) program. A contract will also be placed to purchase a fine-grain layer-by-layer alloy 720 disk for test and evaluation and for several test samples of Ti/TiAl composite materials. All of these materials will be evaluated for quality and performance at Sandia in Albuquerque.

\section{Time Frame:}

Contract duration is planned for 1 year from the time that orders are placed.

\section{Funding Level:}

Expenditures of $\$ 91 \mathrm{~K}$ are planned for a gyrotron tube, $\$ 91 \mathrm{~K}$ for a liquid helium cryostat and supporting hardware, $\$ 10 \mathrm{~K}$ for an alloy 720 disk, and $\$ 10 \mathrm{~K}$ for Ti composites.

\section{Institutes and Individuals Involved:}

Vladimir Skylarevich for the microwave generator and Boris Movchan for the alloy 720 and $\mathrm{Ti}$ composites, Paton Institute, Kiev.

\section{Current Status:}

The contract on the microwave generator was placed in July 1993. Technical details have been worked out for the other projects, and contracts are under negotiation.

\section{References:}

Both of these Ukrainian investigators are internationally known in these fields of work.

\section{Last Update:}

October 1993 


\section{National Security, Nonproliferation, and Counter-Terrorism}

Sandia'a only effort in this category at the present time is in the area of surety technology, i.e., the safety, security, and risk assessment associated with the nation's valuable assets. The program was proposed by the leaders of the two Russian nuclear weapons institutes in April of 1993, with the participation of the two Russian institutes, Los Alamos National Laboratory, Lawrence Livermore National Laboratory, Sandia National Laboratories, and DOE DP 20.1 The program is structured to provide a forum to review the current status of surety technologies in the US and Russia, to identify Russian technologies and technical capabilities that complement US interests, and to identify work of mutual benefit for contracts, technical exchanges, and collaboration.

The program has conducted three symposia: Risk Assessment Technology and Accident Environment Technology, Accident Resistant Container and Transportation Surety Technology, and Hazardous Material Management Technology. Out of these symposia, approximately 300 topics have been identified for potential collaboration, ten contracts for $\$ 310 \mathrm{~K}$ have been signed, twenty contract proposals have been approved by DOE and are in negotiation, and twenty contract topics are in technical development

Sandia will continue to identify proposals of mutual benefit, and will implement contracts and begin technical collaborations on most of the 300 topics identified in the first three symposia. 


\section{Title: \\ Development of an International Vibration Standard for Radioactive Material Packaging}

\section{Point of Contact:}

Robert E. Glass, Sandia National Laboratories, 5161, (505) 845-8742

John A. Andersen, Sandia National Laboratories, 5161, (505) 844-0391

\section{Summary:}

The objective of this program is to develop an international standard that defines the surface transportation vibration environment and provides test methods for demonstrating compliance with the transport requirements of the International Atomic Energy Agency.

Importance: This effort ( 1 ) continues the existing cooperative efforts between Sandia National Laboratories and the All-Russian Research Institute of Experimental Physics on the transport and storage of nuclear materials, (2) permits the resolution of transportation vibration environments and test methods that are of concern to both the Russian and US packaging communities, and (3) provides for an internationally accepted standard where none currently exists.

\section{Deliverables/Time Frame:}

Due Date

(No. of months after

Deliverable contract award)
Russian Effort

in man years

(US Estimate)
Compilation of Russian transportation

environments and regulations

List of additional data needs

Test plans for additional data needs and benchmarks

Additional needs and benchmarking test procedures

Draft vibrations environment envelope

Methodologies test plan

Methodologies test procedures

(continued)
3

0.5

5

0.2

8

0.5

10

0.5

24

0.5

26

0.5

28

1.0 


\section{Due Date Russian Effort}

\section{Deliverable}

(No. of months after

contract award)

Methodologies test report with

benchmark comparisons

Draft test methodologies

recommendations

Draft ISO standard

Participation in International Standards

Organization/Standing Advisory Group

on Safe Transport of Radioactive

Materials (ISO/SAGSTRAM)

\section{Equipment Required and Estimated Cost:}

None required at this time.

Funding Level:

7.7 Russian man years: \$33K
32

36

40

40 to 60
0.5

1.0

1.0

2.0

Institutes and Individuals Involved:

Boris P. Barkanov, VNIIEF - All-Russian Research Institute of Experimental Physics, 831-30

5-68-49

\section{Capability of Russian Lab:}

VNIIEF has the capability to summarize current Russian standards and to provide the engineering required to support the test program and data analyses.

\section{Current Status:}

In process

\section{References:}

None

\section{Last Update:}

February 1994 


\title{
Title: \\ Determination of Small Sample Properties of an Adaptive Filter in Low-Volume Statistical Process Control Applications
}

\author{
Point of Contact: \\ Stephen V. Crowder, Sandia National Laboratories, 12323, (505) 844-0322 \\ Robert G. Easterling, Sandia National Laboratories, 12323, (505) 844-5997
}

\section{Summary:}

This work provides a technical basis for new methods of statistical process control in lowvolume production environments. In particular, the small-sample properties of "filtered" estimators of a process mean and variance are evaluated. After each measurement of a process characteristic, these estimators provide an estimate of the current mean and variance. They also provide updating estimates of the process mean and variance at previous measurement times. The objective of this work is to evaluate the effect of these estimation errors on estimates of the process means and variance. This evaluation will be analytical, to the extent possible; otherwise, computer simulation will be used. The proposed research addresses univariate and multivariate process measurements.

Importance: Many modern manufacturing situations require the production of a small number of specialty-design items. Traditional statistical process control methods (SPC) are suited for large-volume production for which extensive data are available to estimate a process mean and variance. Thus, low-volume SPC methods are required and are the subject of considerable current research. In general, though, small-sample properties of these methods are not known and, consequently, it is not possible for a manufacturer to control the risks of failing to detect an important process shift (meaning degrading quality) or of falsely indicating an important process shift. The proposed work provides this capability and thus enhances the quality of low-volume manufacturing processes.

\section{Deliverables/Time Frame:}

Due Date

(No. of months after

Deliverable
Russian Effort

in man years

(US Estimate)
Report on current statistical process

control processes in Russia. with emphasis

on applications to low-volume production

Report on examples of the use of "error

propagation" methods in Russia

(continued)
2

0.1

2

(). 1 
Due Date

(No. of months after

Deliverable

contract award)
Russian Effort

in man years

(US Estimate)
Review "adaptive filtering" estimators and develop the mathematical framework for addressing crror propagation in this context

Determine the scope of the investigation; sample sizes and parameter ranges

Determine the feasibility of an analytical evaluation of small-sample properties

If an analytical evaluation is not feasible, design a computer simulation experiment to do the evaluation

Conduct the evaluation and report the results
3

0.2

4

0.2

4

0.2

6

12

\section{Equipment Required and Estimated Cost:}

One PC system suitable for conducting Monte Carlo simulations and for providing typed reports, including tables of results: $\$ 3 \mathrm{~K}$

The PC and software will be provided, if available, through obsolete equipment.

Funding Level:

2 Russian man years $\$ 8 \mathrm{~K}$

PC equipment $\$ 3 \mathrm{~K}$

Total $\$ 11 \mathrm{~K}$

Institutes and Individuals Involved:

N. A. Bilyk, Arzamas-16

Capability of Russian Lab:

To be determined

Current Status:

In process

\section{References:}

None

\section{Last Update:}

February 1994 


\section{Title: \\ Development of Numerical Model to Predict the Decomposition and Burn Process of Organic Materials}

\section{Point of Contact:}

Jaime L. Moya, Sandia National Laboratories, 1513, (505) 844-7955

\section{Summary:}

The objective of this investigation is to develop a transient, physically based engineering model that can predict decomposition and burning processes of organic materials, as well as the associated heat transfer through the material. As a first step, this program will focus on developing a numerical tool to predict the thermal response of rigid polyurethane foam (RPF). The approach is to develop a tightly coupled numerical and experimental program that will characterize the dominant physical processes needed to develop a comprehensive predictive tool.

Importance: Over the last decade, RPF has been used to ensure the thermal integrity of numerous shipping containers. Since a comprehensive model that predicts the thermal decomposition and burning of these materials is not available, the success of these programs has relied heavily on costly experimental programs. Historically, to ensure the fire survivability of these foam-based systems, designers have relied on a costly iterative process of design, build, and test, followed by numerous re-designs, re-builds, and re-tests. The development of a satisfactory container design has been limited by the ability of a designer to formulate an effective testing program given the high costs of fabricating prototypes and conducting fire tests.

A tool to predict a priori the fire-induced response of these materials would greatly enhance the ability of a designer to develop a reliable, safe, and cost-effective thermal protection system for hardened containers. In addition, this analytical capability would reduce container development costs and risks by decreasing the programmatic dependency of design evaluation solely on a testing program. The state of knowledge currently requires 3 to 7 years to develop and certify a foam-based system. To meet the demands of designing these containers, the predictive tool proposed here could accelerate the development of these containers.

\section{Deliverables/Time Frame:}

Due Date

(No. of months after

Deliverable contract award)

\section{Russian Effort \\ in man years \\ (US Estimate)}

Program plan

Semi-empirical correlations for thermal physical properties

Results of large-scale experiments

Final report
0.5 


\section{Equipment Required and Estimated Cost:}

One PC system suitable for providing electronic typed reports, date reduction, analysis, etc.: $\$ 5 \mathrm{~K}$ The PC will be provided, if available, through obsolete equipment.

\section{Funding Level:}

Four Russian man years $\quad \$ 18 \mathrm{~K}$

PC equipment $\$ 3 \mathrm{~K}$

Total $\$ 21 \mathrm{~K}$

Institutes and Individuals Involved:

M. Erzin, Arzamas-16

\section{Capabilities of Russian Lab:}

The Russian laboratories have been actively involved in developing thermal response models for energetic materials. Technology they have developed in this area is synergistic with the expertise required to develop a model capable of predicting the fire-induced thermal response of organic materials, as well as the associated heat transfer through material.

\section{Current Status:}

In process

References:

None

Last Update:

February 1994 


\section{Title: \\ Experiments on the Contamination Resulting from Accidental Dispersal of Radioactive Material}

Point of Contact:

Richard Smith, Sandia National Laboratories, 12333, (505) 844-4476

\section{Summary:}

This work involves experimental investigation of environmental contamination as the result of an aerosol release from a simulated accident involving radioactive material (represented by a surrogate material) and high explosives in the proximity of the radioactive material. The program has two phases: (1) investigation of relevant historical data, experimental planning, and long lead item preparation for the experiments to be performed in phase 2 if funded; (2) actual execution of the baseline experiments and of experiments designed to mitigate dispersal consequences.

Importance: The benefit to SNL and to the US community that performs consequence analyses associated with radioactive material dispersal could be significant. These tests should provide unique data on aerosol dispersal cloud parameters such as amount of material involved, cloud size and shape, particle size distribution, ground contamination, etc. Because these tests are expensive and complex, they are rarely performed. The state of consequence prediction modeling could be significantly improved.

\section{Deliverables/Time Frame:}

$\begin{array}{ccc}\text { Due Date } & \text { Russian Effort } \\ \text { Deliverable } & \begin{array}{c}\text { (No. of months after } \\ \text { contract award) }\end{array} & \begin{array}{c}\text { in man years } \\ \text { (US Estimate) }\end{array}\end{array}$

Report on investigation of historical 6 0.5 environmental contamination data to include prior experimental data and applicable accident data if existing and available

Report on detailed experimental plans for 3 baseline experiments

Report on ground contamination predictions from proposed baseline experiments

4 months after 0.8 experiments

(continued) 


\begin{tabular}{ccc} 
Deliverable & $\begin{array}{c}\text { Due Date } \\
\text { (No. of months after } \\
\text { contract award) }\end{array}$ & $\begin{array}{c}\text { Russian Effort } \\
\text { in man years } \\
\text { (US Estimate) }\end{array}$ \\
\hline
\end{tabular}

Report on identification and preliminary

9

0.4

analysis to investigate methods to reduce

release of hazardous material from

accidental explosion

Report on detailed experimental plans for release migration experiments

3 months after

0.4

completion of

experiments

Complete acquisition of long-lead-time equipment for phase 2 effort

$$
\begin{gathered}
6 \text { months after } \\
\text { delivery of report on } \\
\text { detailed experimental } \\
\text { plans }
\end{gathered}
$$

Final study report for phase 1 with conclusions and recommendations for subsequent work continuation in phase 2
2 months after complete acquisition of long-lead-time equipment

\section{$\$ 10 \mathrm{~K}$}

equipment

0.4

\section{Equipment Required and Estimated Cost:}

One PC system suitable for providing electronic typed reports, tables, etc.: $\$ 3 \mathrm{~K}$

The PC will be provided, if available, through obsolete equipment:

Experimental test/analysis equipment: $\$ 10 \mathrm{~K}$

Funding Level: (phase 1 only)

3 Russian man years

$\$ 13 \mathrm{~K}$

PC Equipment

Experimental Equipment

$\$ 10 \mathrm{~K}$

Total $\$ 26 \mathrm{~K}$

\section{Institutes and Individuals Involved:}

Ivan M. Blinov, Head of Laboratory, Designing Division, VNIITF (Chelyabinsk-70) Sergi M. Ylyanov, Head of Scientific Group, Designing Division Igor A. Melyokhin, Head of Scientific Group, Designing Division

This work has been discussed and developed with the VNIITF (Chelyabinsk-70) community at the C-70 conference. Status of the proposal was specifically pursued by VNIITF (Babin and Blinov) during the Albuquerque sonterence. 


\section{Capability of Russian Lab:}

VNIITF is the laboratory that initiated the project proposal. They have a test site and process well defined to perform these tests. Tests would be done in the winter after a snow storm to ensure that the samples would not be contaminated.

\section{Current Status:}

In process

References:

None

\section{Last Update:}

February 1994 


\section{Title:}

\section{Acceptable Risk Criteria-VNIITF}

\section{Point of Contact:}

David D. Carlson, Sandia National Laboratories, 6411, (505) 844-8497

\section{Summary:}

This work provides the technical basis for establishing acceptable risk criteria for hazardous objects or processes, for example, nuclear power plants, explosive operations, and transportation of hazardous cargoes. The work addresses existing societal risks, identification of common elements of existing criteria, and the means by which we confirm that criteria are met. The work is a cooperative US-Russian effort, coordinated by members of Sandia National Laboratories, VNIIEF, and VNIITF.

Importance: The work provides perspective into Russian approaches to formulation of safety criteria. While the US has developed similar criteria for many operations, we are now considering the development of risk-based plutonium dispersal criteria for weapons transport, and we increasingly find risk-based perspectives being introduced into DOE Orders.

\section{Deliverables/Time Frame:}

The entire effort is expected to span 9 months, with delivery of a final report at that time.

\section{Due Date}

(No. of months after Estimated \% of

Deliverable

contract award)

Contract

Formation of the coordinating group and 1 5 determination of hazardous objects or processes to be considered

Analysis of existing societal risks, 20 including risk from natural events and risk from accidents

Identification of common elements of

existing criteria for hazardous objects

Summary of existing criteria for the

hazardous objects under consideration

Summary of means by which we 7 confirm that existing criteria are met

These deliverables will be reviewed by the coordinating group to form perspectives on the technical basis for establishing acceptable risk criteria. 
Equipment Required and Estimated Cost:

1 PC system suitable for providing electronic typed reports, tables, etc.: \$3K

The PC will be provided, if available, through obsolete equipment.

Funding Level:

5 Russian man years $\$ 22 \mathrm{~K}$

PC equipment \$3K

Total $\$ 25 \mathrm{~K}$

Institutes and Individuals Involved:

Stanislav Fedorovich Babin, Chelyabinsk-70

Capability of Russian Lab:

To be determined

Current Status:

In process

References:

None

Last Update:

February 1994 


\section{Title:}

\section{Acceptable Risk Criteria_VNIIEF}

\section{Point of Contact:}

David D. Carlson, Sandia National Laboratories, 6411, (505) 844-8497

\section{Summary:}

This work provides the technical basis for establishing acceptable risk criteria for hazardous objects or processes, for example, nuclear power plants, explosive operations, and transportation of hazardous cargoes. The work addresses existing societal risks, identification of common elements of existing criteria, and the means by which we confirm that criteria are met. The work is a cooperative US-Russian effort, coordinated by members of Sandia National Laboratories, VNIIEF, and VNIITF.

Importance: The work provides perspective into Russian approaches to formulation of safety criteria. While the US has developed similar criteria for many operations, we are now considering the development of risk-based plutonium dispersal criteria for weapons transport, and we increasingly find risk-based perspectives being introduced into DOE Orders.

\section{Deliverables/Time Frame:}

The entire effort is expected to span 9 months, with delivery of a final report at that time.

\section{Due Date}

(No. of months after

Deliverable

\section{Estimated \% of} Contract

Formation of the coordinating group and 1 determination of hazardous objects or processes to be considered

Analysis of existing societal risks, including risk from natural events and risk from accidents

Identification of common elements of

existing criteria for hazardous objects

Summary of existing criteria for the 6 40 hazardous objects under consideration

Summary of means by which we 7 15 5

5


Equipment Required and Estimated Cost:

1 PC system suitable for providing electronic typed reports, tables, etc.: $\$ 3 \mathrm{~K}$

The PC will be provided, if available, through obsolete equipment.

Funding Level:

5 Russian man years $\$ 22 \mathrm{~K}$

PC equipment

$\$ 3 \mathrm{~K}$

Total

$\$ 25 \mathrm{~K}$

Institutes and Individuals Involved:

Vladimir M. Gerasimov, Arzamas-16

Capability of Russian Lab:

To be determined

Current Status:

In process

References:

None

Last Update:

February 1994 


\section{Title: \\ Data Bank Development for Risk Calculations of Complex Technical Systems}

Point of Contact:

Richard Smith, Sandia National Laboratories, 12333, (505) 844-4476

Summary:

The main objective of this work is to develop a data bank or data base for risk calculations associated with the operational safety of complex technical systems such as transportation of hazardous cargo and high pressure tanks for hazardous materials.

Importance: The benefit to SNL is access to a broad scope of Russian accident experiences associated with transportation of hazardous materials and other hazardous operations. This effort as currently proposed is a modest man-year expenditure that could provide significant insight into Russian accident data and potentially significant follow-on work.

Deliverables/Time Frame:

\section{Due Date}

Deliverable

(No. of months after

contract award)
Russian Effort

in man years

(US Estimate)

$\begin{array}{lcc}\text { Report on data bank structure } & 4 & 1 \\ \text { Accident analysis report } & 7 & 0.8 \\ \text { Data bank report } & 10 & 0.8 \\ \text { Final report and briefing } & 12 & 0.4\end{array}$

Equipment Required and Estimated Cost:

One PC system suitable for providing electronic typed reports, tables, etc.: $\$ 8 \mathrm{~K}$

The PC will be provided, if available, through obsolete equipment.

Funding Level:

3 Russian man years

1 PC system

Total
$\$ 13 \mathrm{~K}$

$\$ 8 \mathrm{~K}$

$\$ 21 \mathrm{~K}$

Institutes and Individuals Involved:

V. D. Fomin, V. A. Strashel, and S. M. Ermakov, VNIITF (C-70) 
Capability of Russian Lab:

VNIITF is the laboratory that was involved in the project proposal. This effort had strong selfinitiated support by the Russian contacts.

\section{Current Status:}

In process

References:

None

\section{Last Update:}

February 1994 


\title{
Title: \\ Using Neural Networks to Process Systems Response Data for Probabilistic Risk Assessments
}

\author{
Point of Contact: \\ Jaime L. Moya, Sandia National Laboratories, 1513, (505) 844-7955
}

\section{Summary:}

The purpose of this investigation is to ascertain whether neural networks provide an advantage over interpolation schemes to process system-response data for probabilistic risk assessments. A neural network will be developed to simulate the highly nonlinear response of a system to a predescribed forcing function. The forcing function will consist of four independent variables, and the system response will be characterized by two dependent variables. The investigators will be required to predict the highly nonlinear system response given several nonuniform sparse data sets, which have increasingly greater densities. The data set will be continuous and finite. The system response will be unknown to the investigators. Coincident with the network development, the investigators will use an appropriate interpolation algorithm to process the system-response data. A comparison is to be provided between the network and the interpolation algorithm, and conclusions are to be drawn regarding the efficacy of the neural network. In addition, investigators will determine the feasibility of using a neural network to solve the inverse problem (i.e., given the output, what is the input?). To facilitate development of the network, SNL will provide the investigators with data and a personal computer.

Importance: A major problem in probabilistic risk assessment is our ability to populate event trees with meaningful responses. Neural networks may provide an effective technique to populate event trees with response.

\section{Deliverables/Time Frame:}

\section{Due Date}

(No. of months after

\section{Deliverable}

Document in a letter report the current state-of-the-art of neural networks and their relevance to the stated objective

Deliver an interim report documenting preliminary evaluation of neural network

Deliver a working prototype of neural network

Document in a final report the major accomplishments and their relevance to the stated objective at end

at end 
Equipment Required and Estimated Cost:

One PC system suitable for providing electronic typed reports, tables, etc.: $\$ 8 \mathrm{~K}$ The PC will be provided, if available, through obsolete equipment.

Funding Level:

3 Russian man years $\$ 13 \mathrm{~K}$

$\mathrm{PC}$ equipment $\$ 8 \mathrm{~K}$

Total $\$ 21 \mathrm{~K}$

Institutes and Individuals Involved:

G. A. Novikov, Chelyabinsk-70

Capability of Russian Lab:

Not available

Current Status:

In process

References:

None

Last Update:

February 1994 


\section{Title:}

\section{Russian Probabilistic Risk Assessment (PRA) Methods}

\section{Point of Contact:}

David D. Carlson, Sandia National Laboratories, 6411, (505) 844-8497

Richard E. Smith, Sandia National Laboratories, 12333, (505) 844-4476

\section{Summary:}

This work will provide Sandia National Laboratories a description of risk assessment techniques used in Russia, will identify areas for improvement in these risk assessment techniques, will summarize applications of risk assessment methods, and will characterize "lessons learned" from this experience.

Importance: This work will provide the foundation for understanding Russian capabilities in this field. Differences in approach will become apparent and may lead to improved US approaches as well as Russian improvements. Over the longer term, the basis for joint cooperation will be provided as we understand clearly how our approaches complement each other and areas in which collaboration is mutually beneficial.

\section{Deliverables/Time Frame:}

The entire effort is expected to span 12 months, with delivery of a final report at that time.

\begin{tabular}{lcc} 
& \multicolumn{1}{c}{ Date } \\
Jnths after & Estimated \% of \\
Deliverable & $(\ldots \ldots$ ct award) & Effort \\
\hline
\end{tabular}

\section{Phase 1}

Summary of PRA methods used in

Russia

Description of Russian PRA tools and

data bases

Identification of areas for improvement

(continued) 
Due Date

(No. of months after Estimated \% of

Deliverable initiation of Phase 2)

Effort

\section{Phase 2}

Summary of Russian applications of risk

1

assessment techniques

Description of "lessons learned" from

3

10

Russian PRA applications

Identification of potential joint US-

3

10

Russian PRA applications

\section{Equipment Required and Estimated Cost:}

Two PC systems suitable for providing electronic typed reports, tables, etc.: \$6K

The PCs will be provided, if available, through obsolete equipment.

Funding Level:

Russian Labor Costs:

Phase 1: 4 man years

Phase 2: 4 man years

\$20K initial contract

$\$ 20 \mathrm{~K}$ follow-on contract

Equipment, 2 PCs

$\$ 6 \mathrm{~K}$

Total

$\$ 23 \mathrm{~K}$ (each phase)

Institutes and Individuals Involved:

G. A. Novikov, Chelyabinsk-70

\section{Capability of Russian Lab:}

This work will be performed at Chelyabinsk-70, where there are active investigations into PRA methods and applications. The principal investigators head the PRA and transportation groups, respectively. The institute is fully capable of performing this work.

\section{Current Status:}

In process

\section{References:}

None

Last Update:

February 1994 


\section{Title:}

\section{Proposal for Development of a Glossary of Terminology in Surety Technology by VNIIEF and Sandia National Laboratories}

\section{Point of Contact:}

Patricia Newman, Sandia National Laboratories, 5091, (505) 845-8151

\section{Summary:}

The purpose of this work is to develop a bilingual (Russian-English-Russian) glossary of terms used by Russian and US nuclear institutions engaged in the area of surety technology. The work will be designed for use primarily by translators and interpreters but will also benefit specialists in the field.

Importance: To facilitate efficient collaboration in this area, the Russian and US specialists must understand each other. This requires that the translators and interpreters who transmit the information from one side to the other understand the source language material and use correct terminology in the target language.

Deliverables/Time Frame:

\section{Due Date}

(No. of months after

Deliverable

Deliverable

List of Terms

Definitions in Russian

Bilingual definitions

Completed manuscript

Total

\begin{abstract}
contract award)
\end{abstract}

\author{
Russian Effort \\ in man years \\ (US Estimate)
}

\subsection{5}

3

1.5

6

0.35

9

0.15

Equipment Required and Estimated Cost:

One PC system suitable for providing electronic typed reports, tables, etc.: $\$ 3 \mathrm{~K}$

The PC will be provided, if available, through obsolete equipment.

\section{Funding Level:}

2.5 Russian man pears $\$ 9 \mathrm{~K}$

$\mathrm{PC}$ equipment $\$ 3 \mathrm{~K}$

Total $\$ 12 \mathrm{~K}$ 
Institutes and Individuals Involved:

Lidia A. Il'kaeva, home phone (7-831) 301-1478

VNIIEF

\section{Capability of Russian Lab:}

VNIIEF has technical specialists in accident resistant containers and hazardous materials identification, handling, disposal, and storage and the linguistic expertise in its translation/ interpretation section to gather terminology, draft definitions, and translate the results into English.

\section{Current Status:}

In process

\section{References:}

None

\section{Last Update:}

February 1994 


\section{Title:}

\section{Proposal for Development of a Glossary of Terminology in Surety Technology by VNIITF and Sandia National Laboratories}

\section{Point of Contact:}

Patricia Newman, Sandia National Laboratories, 5091, (505) 845-8151

\section{Summary:}

The purpose of this work is to develop a bilingual (Russian-English-Russian) glossary of terms used by Russian and US nuclear institutions engaged in the area of surety technology. The work will be designed for use primarily by translators and interpreters but will also benefit specialists in the field.

Importance: To facilitate efficient collaboration in this area, the Russian and US specialists must understand each other. This requires that the translators and interpreters who transmit the information from one side to the other understand the source language material and use correct terminology in the target language.

\section{Deliverables/Time Frame:}

Due Date

(No. of months after

Deliverable contract award)
Russian Effort

in man years

(US Estimate)
List of Terms

Definitions in Russian

Bilingual definitions

Completed manuscript

Total
0.25

6

0.35

9

0.15

2.5

\section{Equipment Required and Estimated Cost:}

One PC system suitable for providing electronic typed reports, tables, etc.: $\$ 3 \mathrm{~K}$ The PC will be provided, if available, through obsolete equipment

Funding Level:

2.5 Russian man years $\$ 9 \mathrm{~K}$

PC equipment $\$ 3 \mathrm{~K}$

Total $\$ 12 \mathrm{~K}$ 
Institutes and Individuals Involved:

V. N. Ananiichuk, home phone (7-351) 723-3826

VNIITF

\section{Capability of Russian Lab:}

VNIITF has technical specialists in risk assessment, engineered systems in abnormal environments, and transportation surety and the linguistic expertise in its translation/interpretation section to gather terminology, draft definitions, and translate the results into English.

Current Status:

In process

\section{References:}

None

\section{Last Update:}

February 1994 


\section{Title:}

\section{Full-Scale and Sub-Scale Aircraft Crash and Fire Test-VNIIEF}

\section{Point of Contact:}

Robert K. Thomas, Sandia National Laboratories, 1562, (505) 844-7450

Russell D. Skocypec, Sandia National Laboratories, 1513, (505) 845-8838

\section{Summary:}

The objective of this work is to obtain experimental data on full- and sub-scale cargo aircraft crashes including structural damage, fuel dispersal, and fire. This proposal is for only the first phase, which is to explore the feasibility and develop a test plan for these experiments.

Importance: Cargo aircraft crash and fire accidents have been identified as credible accident scenarios for hazardous cargoes. No instrumental test data is available, and it is not feasible to conduct a sufficient number of tests from which empirical data can be obtained. Thus, current probabilistic risk assessment (PRA) studies rely on numerical simulations of these highly nonlinear events. Our structural and thermal computer codes, however, have not been validated with full-scale test data. DNA and SNL wanted to run these tests for the MMIII/W78 and fireresistant enhancement (FRE) studies, but the cost was prohibitively expensive. This proposal identifies a unique opportunity to acquire the needed data at a feasible cost. By becoming a leader in crash and fire modeling, SNL can apply this technology to future system studies, in addition to other studies for advanced transportation and manufacturing. This work is divided into two parts. Phase 1 is devoted to developing a detailed test plan, and phase 2 is devoted to acquiring hardware and conducting the tests. This proposal addresses phase 1 activities only. DNA is interested in participating and contributing funds for phase 2 . Therefore, SNL's investment will be leveraged.

\section{Deliverables/Time Frame:}

\section{Deliverable}

Due Date

(No. of months after contract award)

\section{Russian Effort in man years (US Estimate)}

Conceptual Test Plan

Preliminary Test Plan
4

6
2

1

\section{Equipment Required and Estimated Cost:}

One PC system suitable for providing electronic typed reports, tables, etc.: $\$ 3 \mathrm{~K}$ The PC will be provided, if available, through obsolete equipment. 
Funding Level:

(Phase 1 only)

3 Russian man years $\$ 13 \mathrm{~K}$

Equipment $\$ 3 \mathrm{~K}$

Total $\$ 16 \mathrm{~K}$

Institutes and Individuals Involved:

S. A. Novikov and A. Mikhailov, VNIIEF (Arzamas-16)

\section{Capability of Russian Lab:}

Instrumented aircraft crash tests of this type and magnitude have not previously been done in the US or Russia. The Russians have conducted large-scale, compiex tests in facilities similar to ours. Their expertise and experience are similar to ours. We may have differing thoughts on instrumentation, but together we can develop an achievable test plan.

\section{Current Status:}

In process

\section{References:}

None

\section{Last Update:}

February 1994 


\section{Title:}

\section{Full-Scale and Sub-Scale Aircraft Crash and Fire Test-VNIITF}

Point of Contact:

Robert K. Thomas, Sandia National Laboratories, 1562, (505) 844-7450

Russell D. Skocypec, Sandia National Laboratories, 1513, (505) 845-8838

\section{Summary:}

The objective of this work is to obtain experimental data on full- and sub-scale cargo aircraft crashes including structural damage, fuel dispersal, and fire. This proposal is for only the first phase, which is to explore the feasibility and develop a test plan for these experiments.

Importance: Cargo aircraft crash and fire accidents have been identified as credible accident scenarios for hazardous cargoes. No instrumental test data is available, and it is not feasible to conduct a sufficient number of tests from which empirical data can be obtained. Thus, current probabilistic risk assessment (PRA) studies rely on numerical simulations of these highly nonlinear events. Our structural and thermal computer codes, however, have not been validated with full-scale test data. DNA and SNL wanted to run these tests for the MMIII/W78 and fireresistant enhancement (FRE) studies, but the cost was prohibitively expensive. This proposal identifies a unique opportunity to acquire the needed data at a feasible cost. By becoming a leader in crash and fire modeling, SNL can apply this technology to future system studies, in addition to other studies for advanced transportation and manufacturing. This work is divided into two parts. Phase 1 is devoted to developing a detailed test plan, and phase 2 is devoted to acquiring hardware and conducting the tests. This proposal addresses phase 1 activities only. DNA is interested in participating and contributing funds for phase 2. Therefore, SNL's investment will be leveraged.

Deliverables/Time Frame:

\begin{tabular}{lcc}
$\begin{array}{c}\text { Due Date } \\
\text { (No. of months after } \\
\text { contract award) }\end{array}$ & $\begin{array}{c}\text { Russian Effort } \\
\text { in man years } \\
\text { (US Estimate) }\end{array}$ \\
\hline
\end{tabular}

Conceptual Test Plan

4

2

Preliminary Test Plan

6

\section{Equipment Required and Estimated Cost:}

One PC system suitable for providing electronic typed reports, tables, etc.: $\$ 3 \mathrm{~K}$

The PC will be provided, if available, through obsolete equipment. 
Funding Level:

(Phase 1 only)

3 Russian man years $\$ 13 \mathrm{~K}$

Equipment $\$ 3 \mathrm{~K}$

Total $\$ 16 \mathrm{~K}$

Institutes and Individuals Involved:

I. M. Blinov and S. F. Babin, VNIITF (Chelyabinsk-70)

\section{Capability of Russian Lab:}

Instrumented aircraft crash tests of this type and magnitude have not previously been done in the US or Russia. The Russians have conducted large-scale, complex tests in facilities similar to ours. Their expertise and experience are similar to ours. We may have differing thoughts on instrumentation, but together we can develop an achievable test plan.

\section{Current Status:}

In process

\section{References:}

None

Last Update:

February 1994 


\section{Title:}

\section{Ground Transportation Test Data Documentation}

\section{Point of Contact:}

Richard Smith, Sandia National Laboratories, 12333, (505) 844-4476

Jaime L. Moya, Sandia National Laboratories, 1513, (505) 844-7955

\section{Summary:}

This work will develop an increased understanding of the severity of potential accidental environments associated with ground transportation of hazardous materials through full-scale and other experiments. A multitask effort will consist of (1) identifying and documenting existing experiments that involve crashes, fires, and other accident environments, and (2) identifying future experiments that would be of mutual benefit to both the US and Russia. Specific future experiments would be identified through a subsequent proposal.

Importance: This work will give SNL a significant understanding of the existing Russian fullscale abnormal-environment test capability as well as a complete set of technical reports on their full-scale and component safety tests to date. They have already had up to a dozen full-scale tests. These tests are typically quite expensive and will provide SNL unique data on extreme abnormal accident environments associated primarily with rail transportation or hazardous cargo. For example, one test resulted in a 12-hour fire. In addition to the direct data, we will be better able to determine their capabilities of performing other tests, such as aircraft crash tests, and to direct their test program to benefit SNL's safety needs.

\section{Deliverables/Time Frame:}

\begin{tabular}{llc} 
Due Date & $\begin{array}{c}\text { Russian Effort } \\
\text { in man years } \\
\text { (US Estimate) }\end{array}$ \\
\hline
\end{tabular}

A letter report documenting the existing

full-scale abnormal-environment tests on

ground transportation systems

A letter report documenting existing

sub-scale and component abnormal-

environment tests on ground

transportation systems

A letter report identifying potential

future tests for the ground transportation

of hazardous cargoes

A briefing on the first 3 deliverables at a 


\section{Equipment Required and Estimated Cost:}

One PC system suitable for providing electronic typed reports, tables, etc.: $\$ 3 \mathrm{~K}$

The $\mathrm{PC}$ will be provided, if available, through obsolete equipment.

Funding Level:

5 Russian man years

1 PC system

Total
$\$ 22 \mathrm{~K}$

$\$ 3 \mathrm{~K}$

$\$ 25 \mathrm{~K}$

Institutes and Individuals Involved:

Anatoli L. Mikhajlov, VNIIEF (Arzamas-16); Phone: 831-30 5-65-09; Telex: 151109 ARSA; Fax: 831-30 5-45-65

Capability of Russian Lab:

Arzamas- 16 is the laboratory that has actually performed full-scale railcar safety tests. These tests may have been joint with or for Russian equivalent of the Dept of Defense.

Current Status:

In process

References:

None

Last Update:

February 1994 


\section{Title:}

\section{Actively Cooled Calorimeter}

\section{Point of Contact:}

Jorman A. (Joe) Koski, Sandia National Laboratories, 6642, MS 0717, (505) 845-9572

\section{Summary:}

About half of the shipping containers that are exposed to fire testing at SNL require some retesting. The goal of this proposal is to reduce the need for expensive retesting by providing accurate engineering models of the fire environment for design purposes. The proposed calorimeter measures heat transfer to cylindrical shapes that are typical of many shipping containers. The active cooling approach has several advantages over previous inertially cooled calorimeters in that accurate measurements of heat transfer are possible for constant temperature surfaces at various heights and orientations. In addition, long-term fire trends can be observed and evaluated.

Importance: This proposal provides an opportunity to obtain, at relatively low cost, a valuable piece of experimental equipment that will benefit several Sandia programs in both the defense and environment areas. The proposed equipment fits nicely with existing Sandia fire research programs and will provide a basis for several joint Sandia-Russian publications in the fire physics literature.

\section{Deliverables/Time Frame:}

Due Date

(No. of months after

Deliverable contract award)
Russian Effort

in man years

(US Estimate)
Summary of existing Russian equipment and procedures

Fabrication of prototype fire sensor

Test of prototype fire sensor

Design of calorimeter

Design and drawing review

Fabrication of final calorimeter, sensors, and support equipment

Final thermal test of calorimeter, sensors and support equipment
1

0.1

2

0.1

3

0.2

5

0.7

6

0.1

11

4

12
0.2 


\section{Equipment Required and Estimated Cost:}

2 IBM PC compatible computers, one requested by Erzin, the other for data acquisition: $\$ 5 \mathrm{~K}$ The $\mathrm{PC}$ will be provided, if available, through obsolete equipment.

\section{Funding Level:}

5.4 Russian man years $\$ 23 \mathrm{~K}$

Russian Equipment Fab. \$20K

PC equipment $\$ 5 \mathrm{~K}$

Total $\$ 48 \mathrm{~K}$

\section{Institutes and Individuals Involved:}

Marat E. Erzin, Deputy Head of Scientific Research, Arzamas-16, 831-30 5-75-85

\section{Capability of Russian Lab:}

During the discussions, the Arzamas-16 representative showed both more interest and experience in the fire diagnostics area than did the Chelabinsk-70 representative. During the poster session Arzamas showed two examples of their experimental fire measurement techniques. Our judgment was that while Chelyabinsk-70 had more fire testing facilities, Arzamas-16 had more interest in understanding the basic fire physics. This led to our recommendation of Arzamas-16.

\section{Current Status:}

In process

\section{References:}

None

Last Update:

February 1994 


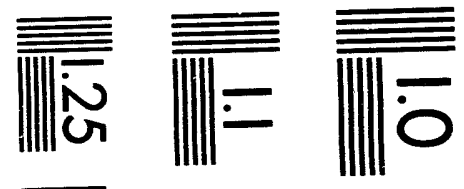

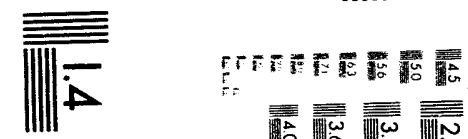

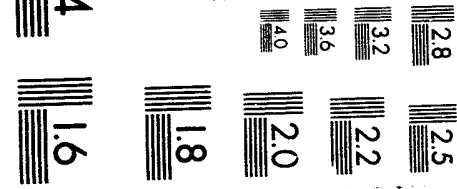




$$
\stackrel{N}{\stackrel{N}{N}}
$$




\section{ritle:}

\section{Wood Impact Limiters (Dampers)—VNIITF}

\section{Point of Contact:}

Wayne M. McMurtry, Sandia National Laboratories, 6642, (505) 845-8502

\section{Summary:}

Extreme interest has been exhibited by both Russia and the US in using woods as "impact limiters" (US terminology) or "dampers" (Russian terminology) in container and transportation applications. An expanded data set and an improved behavioral model are needed to further analyze the suitability of these woods as impact limiters. It is desired to issue a contract to the Russians to study US redwood and other types of Russian woods with similar characteristics for use as impact limiters.

Importance: The work would establish mechanical and physical characteristics for the woods - such as crush strength under varying load rates, temperature, moisture content and grain angle - and incorporate this information into an improved model. The benefit to SNL and to the US community that designs and tests containers could be significant, considering the increasing need for materials of this type that can demonstrate compliance with the stringent regulatory requirements.

\section{Deliverables/Time Frame:}

Due Date

(No. of months after

\section{Deliverable}

Preparation of preliminary report on any work completed in subject area

Preparation of technical proposals detailing experimental plan

Construction of test apparatus and preparation of data analysis system

Execution of experiments and data analysis

Development of suitable model capable of being used to predict limiter response under accident conditions

Preparation of final report to include all experimental data and analysis and details associated with behavioral model contract award)

\section{Russian Effort in \\ man years \\ (US Estimate)}

0.1

0.3

5

17

18
0.1 
Equipment Required and Estimated Cost:

One PC system: \$3K

The PC will be provided, if available, through obsolete equipment.

Miscellaneous materials and laboratory supplies: \$2K

Funding Level:

3.5 Russian man years $\$ 15 \mathrm{~K}$

PC Equipment \$3K

Laboratory Supplies $\$ 2 \mathrm{~K}$

Total \$20K

Institutes and Individuals Involved:

Ivan M. Blinov, Head of Laboratory, VNIITF (Chelyabinsk-70)

Capability of Russian Lab:

VNIITF is believed to have testing capability in this area.

Current Status:

In process

References:

None

Last Update:

February 1994 


\section{Title:}

\section{Wood Impact Limiters (Dampers) —VNIIEF}

\section{Point of Contact:}

Wayne M. McMurtry, Sandia National Laboratories, 6642, (505) 845-8502

\section{Summary:}

Extreme interest has been exhibited by both Russia and the US in using woods as "impact limiters" (US terminology) or "dampers" (Russian terminology) in container and transportation applications. An expanded data set and an improved behavioral model are needed to further analyze the suitability of these woods as impact limiters. It is desired to issue a contract to the Russians to study US redwood and other types of Russian woods with similar characteristics for use as impact limiters.

Importance: The work would establish mechanical and physical characteristics for the woods - such as crush strength under varying load rates, temperature, moisture content and grain angle-and incorporate this information into an improved model. The benefit to SNL and to the US community that designs and tests containers could be significant, considering the increasing need for materials of this type that can demonstrate compliance with the stringent regulatory requirements.

\section{Deliverables/Time Frame:}

Due Date

(No. of months after

Deliverable

Preparation of preliminary report on any

work completed in subject area

Preparation of technical proposals detailing experimental plan

Construction of test apparatus and preparation of data analysis system

Execution of experiments and data analysis

Development of suitable model capable of being used to predict limiter response under accident conditions

Preparation of final report that is to include all experimental data and analysis and the details associated with the behavioral model

\section{Russian Effort in \\ man years \\ (US Estimate)}

contract award)

3

0.1

3

0.3

5

0.2

16

2.5

17

0.3

18

0.1 


\section{Equipment Required and Estimated Cost:}

One PC system: $\$ 3 \mathrm{~K}$

The PC will be provided, if available, through obsolete equipment.

Miscellaneous materials and laboratory supplies: $\$ 2 \mathrm{~K}$

\section{Funding Level:}

3.5 Russian man years $\$ 15 \mathrm{~K}$

PC Equipment \$3K

Laboratory Supplies $\$ 2 \mathrm{~K}$

Total \$20K

Institutes and Individuals Involved:

S. Novikov, Head of Scientific Research, VNIIEF (Arzaimas-16)

Capability of Russian Lab:

VNIIEF is the lead Russian lab on the container design and production effort under the SSD exchange. Their experience with containers and wood dampers seems to be extensive.

\section{Current Status:}

In process

\section{References:}

None

\section{Last Update:}

February 1994 


\section{Title:}

\section{Penetration Technology}

\section{Point of Contact:}

Robert K. Thomas, Sandia National Laboratories, 1562, (505) 844-7450

William F. Hartman, Sandia National Laboratories, 9614, (505) 844-6937

\section{Summary:}

The objective of this work is to generate experimental data and develop empirical models of the penetration of the representative container cross sections by both small arms projectiles and penetrator probes typically generated in ground transportation and aircraft crashes. This work will gain SNL access to Russian test data and models on bullet and fragmerit penetration.

Importance: SNL currently does not have a model to determine vulnerabilities to small arms fire, and each cross section must be individually tested. In both the W76 and W78 probabilistic risk assessment (PRA) studies, penetration by probes was found to be a credible abnormal accident. Only a few probe penetration experiments have been conducted even though this data is critical to validating the structural computer codes. Currently, there is no funding in the NSAFE and weapon container budgets for FY94 to conduct these types of tests.

\section{Deliverables/Time Frame:}

$\begin{array}{ccc}\begin{array}{c}\text { Due Date } \\ \text { (No. of months after } \\ \text { contract award) }\end{array} & \begin{array}{c}\text { Russian Effort } \\ \text { in man years } \\ \text { (US Estimate) }\end{array}\end{array}$

Document existing Russian data and models on bullet and fragment penetration

Conduct 10 to 12 bullet tests on US container cross sections

Conduct 6 probe tests on US container cross sections
3

1

\section{Equipment Required and Estimated Cost:}

One PC system suitable for providing electronic typed reports, tables, etc: $\$ 3 \mathrm{~K}$ The PC will be provided, if available, through obsolete equipment.

\section{Funding Level:}

$\begin{array}{lr}3.5 \text { Russian man years } & \$ 15 \mathrm{~K} \\ \text { PC Equipment } & \$ 3 \mathrm{~K} \\ \text { Material } & \$ 2 \mathrm{~K} \\ \text { Total } & \$ 20 \mathrm{~K}\end{array}$


Institutes and Individuals Involved:

Ivan Blinov, Chelyabinsk-70

\section{Capability of Russian Lab:}

The Russian laboratories have conducted bullet penetration tests for many years and have accumulated a sizable data base. Because the probe experiments are closely related, there is a high probability this effort will be successful.

\section{Current Status:}

In process

\section{References:}

None

\section{Last Update:}

February 1994 


\section{Title: \\ Impact Limiter Materials Aging Study}

\section{Point of Contact:}

Robert E. Glass, Sandia National Laboratories, 5161, (505) 845-8742

John A. Andersen, Sandia National Laboratories, 5161, (505) 844-0391

\section{Summary:}

This proposal provides the basis for extending the package-specific aging studies being performed on the AT-400R Russian Fissile Material Container to a broad range of impact limiting materials that could be considered for use in radioactive-material packages by either Russia or the US. The study will develop methodologies for direct experimental correlation between accelerated aging and normal aging results for these materials. It will lead to a longterm experimental program addressing specific aging characteristics of packaging materials. By incorporating these studies in a bilateral cooperative effort, this work should enhance the mutual acceptability of packages developed in each country.

Importance: This effort (1) continues the existing cooperative efforts between Sandia National Laboratories and the All-Russian Research Institute of Experimental Physics on packagingspecific issues, (2) permits resolution of the aging issue that is of concern to both the Russian and the US packaging communities, (3) will lead to definition of methods for extending data available on the aging of materials that are being used in the design and licensing of radioactivematerial packaging, and (4) provides a direct correlation between normal and accelerated aging techniques.

Deliverables/Time Frame:

$\begin{array}{ccc}\text { Due Date } & \text { Russian Effort } \\ \text { Deliverable } & \begin{array}{c}\text { (No. of months after } \\ \text { contract award) }\end{array} & \begin{array}{c}\text { in mears } \\ \text { (US Estimate) }\end{array}\end{array}$

Draft test methodology proposal

Test procedures for accelerated aging

Test plans and procedures for normal aging testing

Final report
3

9

9

18
0.75

0.75

0.5

0.5

Equipment Required and Estimated Cost:

None

Funding Level:

2.5 Russian man years $\quad \$ 11 \mathrm{~K}$ 


\section{Institutes and Individuals Involved:}

Boris P. Barkanov, Arzamas-16

\section{Capability of Russian Lab:}

VNIIEF has the capability to subject the range of materials to the environments that are specified in the statement of work. Further, VNIIEF has been instrumental in defining these environments in joint work with Sandia National Laboratories.

\section{Current Status:}

In process

\section{References:}

None

Last Update:

February 1994 


\section{Title:}

\section{Seals Testing, Dynamic and Static-VNIITF}

\section{Point of Contact:}

Wayne M. McMurtry, Sandia National Laboratories, 6642, (505) 845-8502

\section{Summary:}

An interest has been expressed both by the US and Russia to address two significant issues associated with the seals for containers and other assemblies: (1) the need to dynamically establish the spring modulus of several types of elastomers that are used as "O-ring" seals and to use this spring modulus data in the development of an appropriate model of O-ring seal behavior; (2) the need to determine experimentally what level of assault during an accident would result in leakage past an $\mathrm{O}$-ring seal and to compare this behavior with predictions from the model of O-ring seal behavior.

Importance: These tests should provide unique data on the physical and mechanical behavior of O-rings and a resulting unique behavioral model. Bringing together the resources and expertise of SNL, VNIIEF (Arzamas-16), and VNIITF (Chelyabinsk-70) to address these issues is an unusual opportunity to truly advance the state of knowledge for this technology.

\section{Deliverables/Time Frame:}

Due Date

(No. of months after

Deliverable

Preparation of preliminary report on any

work completed in subject arcas

Preparation of technical proposals detailing experimental plans

Construction of test apparatus and preparation of data analysis system

Execution of experiments and data analysis

Development of suitable model capable of being used to predict $\mathrm{O}$-ring response under accident conditions

Preparation of final report to include all experimental data and analysis and details associated with behavioral model contract award)

\section{Russian Effort in \\ man years \\ (US Estimate)}

0.1

0.2

5

0.3

16

2.5

17

0.3

18

0.1 
Equipment Required and Estimated Cost:

One PC system: $\$ 3 \mathrm{~K}$

The PC will be provided, if available, through obsolete equipment.

Miscellaneous materials and laboratory supplies: $\$ 2 \mathrm{~K}$

Funding Level:

3.5 Russian man years $\$ 15 \mathrm{~K}$

PC Equipment $\$ 3 \mathrm{~K}$

Laboratory Supplies $\quad \$ 2 \mathrm{~K}$

Total $\$ 20 \mathrm{~K}$

Institutes and Individuals Involved:

Viktor Borisovich Skrynnikov, VNIITF (Chelyabinsk-70)

Capability of Russian Lab:

VNIITF is believed to have considerable testing capability in this area.

Current Status:

In process

References:

None

Last Update:

February 1994 


\section{Title:}

\section{Seals Testing, Dynamic and Static-VNIIEF}

\section{Point of Contact:}

Wayne M. McMurtry, Sandia National Laboratories, 6642, (505) 845-8502

\section{Summary:}

An interest has been expressed both by the US and Russia to address two significant issues associated with the seals for containers and other assemblies: (1) the need to dynanically establish the spring modulus of several types of elastomers that are used as "O-ring" seals and to use this spring modulus data in the development of an appropriate model of O-ring seal behavior; (2) the need to determine experimentally what level of assault during an accident would result in leakage past an O-ring seal and to compare this behavior with predictions from the model of O-ring seal behavior.

Importance: These tests should provide unique data on the physical and mechanical behavior of O-rings and a resulting unique behavioral model. Bringing together the resources and expertise of SNL, VNIIEF (Arzamas-16), and VNIITF (Chelyabinsk-70) to address these issues is an unusual opportunity to truly advance the state of knowledge for this technology.

\section{Deliverables/Time Frame:}

(No. of months after

\section{Deliverable}

Preparation of preliminary report on any

work completed in subject areas

Preparation of technical proposals detailing experimental plans

Construction of test apparatus and preparation of data analysis system

Execution of experiments and data analysis

Development of suitable model capable of being used to predict $\mathrm{O}$-ring response under accident conditions

Preparation of final report to include all experimental data and analysis and details associated with behavioral model

\section{Due Date}

contract award)
3

3

5

16

17

18

\section{Russian Effort in man years (US Estimate)}

0.2

0.5

0.5

0.2 


\section{Equipment Required and Estimated Cost:}

One PC system: $\$ 6 \mathrm{~K}$

The PC will be provided, if available, through obsolete equipment.

Miscellaneous materials and laboratory supplies: \$3K

Funding Level:

6.9 Russian man years $\$ 30 \mathrm{~K}$

PC Equipment $\$ 6 \mathrm{~K}$

Laboratory Supplies $\quad \$ 3 \mathrm{~K}$

Total $\$ 39 \mathrm{~K}$

Institutes and Individuals Involved:

Boris P. Barkinov, Deputy Chief, VNIIEF (Arzamas-16)

Capability of Russian Lab:

VNIIEF is the lead Russian lab on the container design and production effort under the safety, security, and dismantlement (SSD) exchange. Their experience with containers, and thus components such as seals, is believed to be extensive.

\section{Current Status:}

In process

References:

None

Last Update:

February 1994 


\section{Title:}

\section{Analysis of Safety During Rail Transportation of Hazardous Cargo}

\section{Point of Contact:}

Keith Almquist, Sandia National Laboratories, 4111, (505) 844-2606

Robert Huelskamp, Sandia National Laboratories, 4112, (505) 844-0496

Garry Brown, Sandia National Laboratories, 4111, (505) 844-3646

\section{Summary:}

To develop a data base and a better understanding of accidents on the Russian rail system involving the shipment of hazardous cargo.

Importance: This work will help SNL (1) evaluate the relative importance of current safety, security, and dismantlement (SSD) activities and (2) define and understand other steps that can be taken to improve the safety of any radioactive shipments in the future.

Deliverables/Time Frame:

$\begin{array}{ccc} & \text { Due Date } & \text { Russian Effort } \\ \text { Deliverable } & \begin{array}{c}\text { (No. of months after } \\ \text { contract award) }\end{array} & \text { (US Estimate) }\end{array}$

Narrative of operations

Preliminary data

Complete data base

Probability density function

Analysis
3

3

10

10

10
1

0.25

2.5

1.0

1.0

Equipment Required and Estimated Cost:

One PC system suitable for providing electronic typed reports, tables, etc.: $\$ 3 \mathrm{~K}$ The PC will be provided, if available, through obsolete equipment.

\section{Funding Level:}

5.75 Russian man years

PC Equipment

Total

Institutes and Individuals Involved:

Gennady Novikov and Stansily Babin, Chelyabinsk-70
$\$ 25 \mathrm{~K}$

$\$ 3 \mathrm{~K}$

$\$ 28 \mathrm{~K}$ 


\section{Capability of Russian Lab:}

Chelyabinsk-70 is believed to have done considerable work of this type in the past.

\section{Current Status:}

In process

\section{References:}

None

Last Update:

February 1994 


\section{Title:}

\section{2-D and 3-D Numerical Simulations for Structural and Thermal Benchmark Problems-VNIITF}

\section{Point of Contact:}

Robert K. Thomas, Sandia National Laboratories, 1562, (505) 844-7450

Russell D. Skocypec, Sandia National Laboratories, 1513, (505) 845-8838

\section{Summary:}

The objective of this work is to benchmark 2-1D and 3-D numerical simulation codes used at Russian and US laboratories. The codes of interest are those used for nonlinear, numerical simulation of abnormal environments involving crash dynamics and fire.

Importance: This project is a cooperative effort among VNIITF, VNIIEF, and the three US labs. This work offers the US a unique opportunity to evaluate Russian technology in the areas of analytical methods, code architecture, and numerical algorithms. The Russians are known to have expertise in analytical and empirical solutions to structural and thermal problems; these solution methods would enhance our simulation capability as well as provide insight into simplified models for probabilistic risk assessment (PRA) of weapon systems.

\section{Deliverables/Time Frame:}

\section{Due Date}

(No. of months after

Deliverable

$$
\text { contract award) }
$$

Russian Effort in man years

(US Estimate)
Project Plan

Structural benchmark problems

Thermal benchmark problems

Complex problem set
3

6

9

12

\section{5}

0.5

0.5

0.5

\section{Equipment Required and Estimated Cost:}

One PC system suitable for providing electronic typed reports, tables, etc.: $\$ 3 \mathrm{~K}$ The PC will be provided, if available, through obsolete equipment.

Funding Level:

2 Russian man years $\$ 9 \mathrm{~K}$

PC equipment $\$ 3 \mathrm{~K}$

Total $\$ 12 \mathrm{~K}$

Institutes and Individuals Involved:

Leonid Shibarshov, Chelyabinsk-70. 


\section{Capability of Russian Lab:}

The Russian laboratories are fully capable of conducting numerical simulations of structural and thermal problems. We do not know the capability of their codes to conduct detailed, complex crash dynamics and fire modeling. We will start with simplified geometries and material models, and then extend the models to include nonlinearities. No software will be exchanged between Russian and US laboratories.

\section{Current Status:}

In process

\section{References:}

None

\section{Last Update:}

February 1994 


\section{Title:}

\section{2-D and 3-D Numerical Simulations for Structural and Thermal Benchmark Problems-VNIIEF}

\section{Point of Contact:}

Robert K. Thomas, Sandia National Laboratories, 1562, (505) 844-7450

Russell D. Skocypec, Sandia National Laboratories, 1513, (505) 845-8838

\section{Summary:}

The objective of this work is to benchmark 2-D and 3-D numerical simulation codes used at Russian and US laboratories. The codes of interest are those used for nonlinear, numerical simulation of abnormal environments involving crash dynamics and fire.

Importance: This project is a cooperative effort among VNIITF, VNIIEF, and the three US labs. This work offers the US a unique opportunity to evaluate Russian technology in the areas of analytical methods, code architecture, and numerical algorithms. The Russians are known to have expertise in analytical and empirical solutions to structural and thermal problems; these solution methods would enhance our simulation capability as well as provide insight into simplified models for probabilistic risk assessment (PRA) of weapon systems.

\section{Deliverables/Time Frame:}

$\begin{array}{ccc}\text { Due Date } & \text { Russian Effort } \\ \text { (No. of months after } & \text { in man years } \\ \text { contract award) } & \text { (US Estimate) }\end{array}$

Project plan

Structural benchmark problems

Thermal benchmark problems

Complex problem set
3

6

9

12
0.5

0.5

0.5

0.5

\section{Equipment Required and Estimated Cost:}

One PC system suitable for providing electronic typed reports, tables, etc.: $\$ 3 \mathrm{~K}$ The PC will be provided, if available, through obsolete equipment.

Funding Level:

2 Russian man years $\$ 9 \mathrm{~K}$

PC equipment $\$ 3 \mathrm{~K}$

Total $\$ 12 \mathrm{~K}$

Institutes and Individuals Involved:

Viktor Markelov and Vitali Vetveyev, Arzamas-16. 


\section{Capability of Russian Lab:}

The Russian laboratories are fully capable of conducting numerical simulations of structural and thermal problems. We do not know the capability of their codes to conduct detailed, complex crash dynamics and fire modeling. We will start with simplified geometries and material models, and then extend the models to include nonlinearities. No software will be exchanged between Russian and US laboratories.

\section{Current Status:}

In process

\section{References:}

None

\section{Last Update:}

February 1994 


\section{Title:}

\section{Measurements of Temperature and Heat Flux in Fires}

\section{Point of Contact:}

Ned Keltner, Sandia National Laboratories, 2761, (505) 845-3189

\section{Summary:}

The objective of this program is to improve our understanding of thermal measurements in abnormal-environment fires. A coupled experimental analytical program is proposed to: (1) measure temperatures, heat fluxes, and velocities in pool fires and heat transfer to a calorimeter that is similar in size to smaller shipping containers; (2) evaluate the factors that introduce the largest uncertainties into the measurements; and (3) develop correlations between temperature and heat flux that are suitable for use in probabilistic risk assessments (PRAs).

Importance: There is a continuing need to improve our understanding of abnormal environments and how they can affect safety. SNL has ongoing programs related to this activity, and DNA has a related large program on fire safety assessment.

\section{Deliverables/Time Frame:}

Due Date

(No. of months after

Deliverable contract award)

\section{Russian Effort \\ in man years \\ (US Estimate)}

Develop draft program plan

Letter report that describes the experimental program along with the experimental data and pictures of the test setup

Final report with a detailed description of both the experimental and analytical programs and their results; hard copy and electronic media formats of experimental data along with any analyses of this data
3

9

0.2

1.9

12

\section{Equipment Required and Estimated Cost:}

One PC system suitable for providing electronic typed reports, tables, etc.: $\$ 3 \mathrm{~K}$ The PC will be provided, if available, through obsolete equipment. 
Funding Level:

3.1 Russian man years $\$ 13 \mathrm{~K}$

Materials (consumable) $\$ 14 \mathrm{~K}$

PC Equipment \$3K

Total: $\quad \$ 30 \mathrm{~K}$

Institutes and Individuals Involved:

M. Erzin, VNIIEF, (Arzamas-16), 831-30 5-57-85

\section{Capability of Russian Lab:}

VNIIEF conducts pool fire tests of shipping containers. Based on two symposium posters, they have developed integral equation and inverse heat conduction techniques for evaluating and comparing different fire environments. This work is complementary to work at SNL.

\section{Current Status:}

In process

References:

None

\section{Last Update:}

February 1994 


\section{Title:}

\section{Fuel-Fire Characterization and Object Response}

\section{Point of Contact:}

Russell D. Skocypec, Sandia National Laboratories, 1513, (505) 844-8838

Jaime L. Moya, Sandia National Laboratories, 1513, (505) 844-7955

Ned Keltner, Sandia National Laboratories, 2761, (505) 845-3189

\section{Summary:}

This program will: (1) characterize the thermal environment in the VNIITF fire test facility, (2) generate experimental data to validate and further develop fire models, (3) compare experimental data to open-pool-fire test data, and (4) quantify the thermal response of simulated inert shipping containers and containers with high explosives immersed in a fire.

The work will be conducted in three phases (three years). The first phase of the program focuses on development of fire diagnostics, experimental characterization of the fire, and fabrication of several simulated shipping containers. The simulated shipping containers will be tested after characterizing the fire environment. The first set of containers will be designed to facilitate the quantification of the relative thermal performance of various impact/thermal mitigating materials (redwood, ceramic fiber insulation, and polyurethane foam) currently used in the design of hardened shipping containers. The second set of containers (containers with high explosives) will be designed, fabricated, and tested during the second and third years of the program, respectively. These containers will contain both nondamaged or mechanically damaged explosives.

Importance: This integrated program provides SNL with an opportunity to obtain crucial and unique experimental data for the ongoing development of fire models, the evaluation of impact/thermal mitigating materials used in hardened containers, and the characterization of the fire-induced response of energetic materials. This crucial data can be obtained inexpensively at the Russian facility.

\section{Deliverables/Time Frame:}

Due Date

(No. of months after

Deliverable contract award)

\author{
Russian Effort \\ in man years \\ (US Estimate)
}

Program plan

Characterizing the fire environment

Fabrication of simulated containers

Final report
3

10

11

12
1

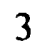

3

0.5 


\section{Equipment Required and Estimated Cost:}

One PC system suitable for providing electronic typed reports, data reduction, analysis, etc. : $\$ 5 \mathrm{~K}$

The PC will be provided, if available, through obsolete equipment.

Funding Level:

7.5 Russian man years $\$ 35 \mathrm{~K}$

Equipment

$\$ 5 \mathrm{~K}$

Total

$\$ 40 \mathrm{~K}$

Institutes and Individuals Involved:

V. Modin and S. Subbotin, VNIITF (Chelyabinsk-70)

Capabilities of Russian Lab:

The VNIITF enclosed, large, fire-testing facility is capable of testing objects weighing up to 2 tons and containing up to $200 \mathrm{~kg}$ of high explosives. Temperatures between $600^{\circ} \mathrm{C}$ and $1000^{\circ} \mathrm{C}$ can be achieved by varying the fuel mass rate into the facility. Fire test data from this facility complements that which can be obtained at SNL.

\section{Current Status:}

In process

References:

None

Last Update:

February 1994 


\section{Title:}

\section{Explosion-Resistant Container Development}

\section{Point of Contact:}

Donald J. Bohrer, Sandia National Laboratories, 5202, MS9006, (510) 294-3111

Kevin E. Carbiener, Sandia National Laboratories, 5365, MS9035, (510) 294-2694

\section{Summary:}

This project will develop designs for explosion-resistant containers for safe handling and transportation of generic conventional explosive devices. The goal of these designs will be complete containment of both the explosive force and any hazardous byproducts of the unknown explosive.

Importance: This project will use the experience and expertise of the Russian Research Institute of Experimental Physics to develop a class of explosive containers not common to the experience of the US National Laboratories. It will develop this technology at a low cost and will fit well with Sandia responsibilities for transportation safety and accident-resistant containers. Whereas there are potential uses within Sandia for the container designs developed in this project, the greatest potential applicability would be for commercial and local government uses, which gives Sandia additional technology transfer opportunities.

\section{Deliverables/Time Frame:}

$\begin{array}{ccc}\begin{array}{c}\text { Due Date } \\ \text { (No. of months after } \\ \text { contract award) }\end{array} & \begin{array}{c}\text { Russian Effort } \\ \text { in man years } \\ \text { (US Estimate) }\end{array}\end{array}$

\begin{tabular}{lcc}
\hline Conceptual design presentation & 2 & 0.9 \\
Preliminary design report & 6 & 1.1 \\
Feasibility study results & 10 & 2.0 \\
Test plan & 11 & 0.5 \\
Final project report & 12 & 0.6
\end{tabular}

\section{Equipment Required and Estimated Cost:}

One PC system suitable for simple finite-element calculations and for providing electronic typed reports, tables, etc.: $\$ 3 \mathrm{~K}$

The PC will be provided, if available, through obsolete equipment. 
Funding Level:

5.1 Russian man years $\$ 22 \mathrm{~K}$

Scale Model Test Hardware $\$ 5 \mathrm{~K}$

PC Equipment \$3K

Total \$30K

\section{Institutes and Individuals Involved:}

Anatoli L. Mikhailov, Deputy Head of Gas Dynamics Div., VNIIEF (Arzamas-16),

Phone 831-30 5-65-09, Fax 831-30 5-45-65

Anatoli G. Ivanov, Head of Dynamics Strength Dept., VNIIEF (Arzamas-16),

Phone 831-30 5-65-09, Fax 831-30 5-45-65

\section{Capability of Russian Lab:}

During the discussions, both Arzamas-16 and Chelyabinsk-70 showed interest in this project and indicated capabilities in container design. However, Arzamas-16 was most involved in discussing the details of this particular project, and their papers presented at the Albuquerque symposium indicated a greater depth of experience in designing containers similar to those in this project.

\section{Current Status:}

In process

References:

None

\section{Last Update:}

February 1994 


\section{Title:}

\section{Security Tag and Seal for Fissile Material Container}

Point of Contact:

John C. Matter, Sandia National Laboratories, 9249, (505) 845-8103

\section{Summary:}

The objective of this project is to develop a security tag and seal system for application to fissile material containers.

Importance: Fissile material containers are used for the safe transport and secure storage of a variety of fissile materials. Material owners and custodians need assurance that no one has tampered with the material during unattended periods. Security tags and seals are an important element of a verification system.

Deliverables/Time Frame:

Due Date (No. of months after

Deliverable

Project plan

Requirements document

System design

Design review

Manufacturing instructions

Test plan

Test results

User manual

Demonstration

Final report contract award)
Russian Effort

in man years

(US Estimate)
1

2

0.2

4

1.0

5

0.2

6

0.5

6

0.2

9

0.5

11

0.2

11

0.2

12

Equipment Required and Estimated Cost:

One fissile material container: $\quad \$ 2 \mathrm{~K}$

Materials for tag, seal, verifier: $\quad \$ 3 \mathrm{~K}$ 
Funding Level:

3.4 Russian man years $\quad \$ 15 \mathrm{~K}$

Equipment and Material $\$ 5 \mathrm{~K}$

Total \$20K

Institutes and Individuals Involved:

Boris Barkanov, Arzamas-16

\section{Capability of Russian Lab:}

In discussions with the Russians, SNL personnel have been told that Arzamas-16 staff have designed secure bolts and locks for specific containers.

\section{Current Status:}

In process

\section{References:}

None

\section{Last Update:}

February 1994 
Intentionally Left Blank 


\section{DISTRIBUTION:}

1 M. Krebs

U.S. Department of Energy

Office of Energy Research, ER-1

1000 Independence Ave. S.W

Washington, DC 20585

1 Assistant Secretary,

Conservation \& Renewable Energy, CE-1

U.S. Department of Energy 1000 Independence Ave. S.W.

Washington, DC 20585

1 J.S. Siegel, Actg. Assistant Secretary, Fossil Energy, FE-1

U.S. Department of Energy 1000 Independence Ave. S.W.

Washington, DC 20585

1 D. Dreyfus

Nuclear Energy, NE-1

U.S. Department of Energy 1000 Independence Ave. S.W.

Washington, DC 20585

1 V.H. Reis, Assistant Secretary, Defense Programs, DP-1

U.S. Department of Energy 1000 Independence Ave. S.W.

Washington, DC 20585

1 T. F. McBride, Assistant Secretary

Environmental Restoration and Waste

Management, EM-1

U. S. Department of Energy

1000 Independence Ave. S.W

Washington, DC 20585

4 U.S. Department of Energy

Attn: W. Chernock, DP-4 (1)

M. Katz, DP-4.2 (3)

1000 Independence Ave. S.W.

Washington, DC 20585
1 S. Kahalas, DP-24

U.S. Department of Energy 19901 Germantown Rd.

Germantown, MD 20874

1 J. Turner, DP-20.1

U.S. Department of Energy

19901 Germantown Rd.

Germantown, MD 20874

1 H. Jaffe, PO-70

U.S. Department of Energy 1000 Independence Ave. S.W.

Washington, DC 20585

1 J. Keliher, IS-1

U.S. Department of Energy 1000 Independence Ave. S.W.

Washington, DC 20585

3 V.E. Alessi, IS-40

U.S. Department of Energy 1000 Independence Ave, S.W.

Washington, DC 20585

3 G. Bradshaw, IS-40

U.S. Department of Energy 1000 Independence Ave. S.W.

Washington, DC 20585

2 United States Department of State

Attn: A. Harrington

A. Wasserman

2201 C Street N.W.

Washington, DC 20520

1 The Honorable James E. Goodby

U.S. Ambassador

U.S. Negotiator on Safe and Secure

Dismantlement

United States Department of State

2201 C Street N.W.

Washington, DC 20520 


\section{DISTRIBUTION (continued):}

\section{J. Birely}

U.S. DoD/OATSD (AE)

The Pentagon

Room 3E 1086

Washington, DC 20301

1 D. Gilmore

U.S. Dept. of Commerce

Rm 3878

14th St. and Constitution Ave. N.W.

Washington DC 20230

1 W. Dunlop, L205

Lawrence Livermore National Lab

PO Box 808

Livermore, CA 94550

$\begin{array}{lll}1 & \text { MS } 0463 & \text { R. L. Hagengruber, } 5000 \\ 5 & \text { MS } 0469 & \text { P. Stokes, 5004 } \\ 1 & \text { MS 0467 } & \text { J. Wirth, 5090 } \\ 15 & \text { MS 0467 } & \text { D. Nokes, 5091 } \\ 1 & \text { MS 0725 } & \text { T. Hunter, 6900 } \\ 1 & \text { MS 0769 } & \text { D. Miyoshi, 5800 } \\ 1 & \text { MS 0766 } & \text { J. Kelsey, 9600 } \\ 1 & \text { MS 0321 } & \text { E. Baris, 1400 } \\ 1 & \text { MS 1190 } & \text { D. Cook, 1200 } \\ 1 & \text { MS 0337 } & \text { A. Roming, 1800 } \\ 1 & \text { MS } 9018 & \text { Central Technical Files, 8523-2 } \\ 5 & \text { MS 0899 } & \text { Technical Library, 7141 } \\ 1 & \text { MS 0619 } & \text { Technical Publications, 7151 } \\ 10 & \text { MS } 0100 & \text { Document Processing, 7613-2 } \\ & & \text { For DOE/OSTI }\end{array}$




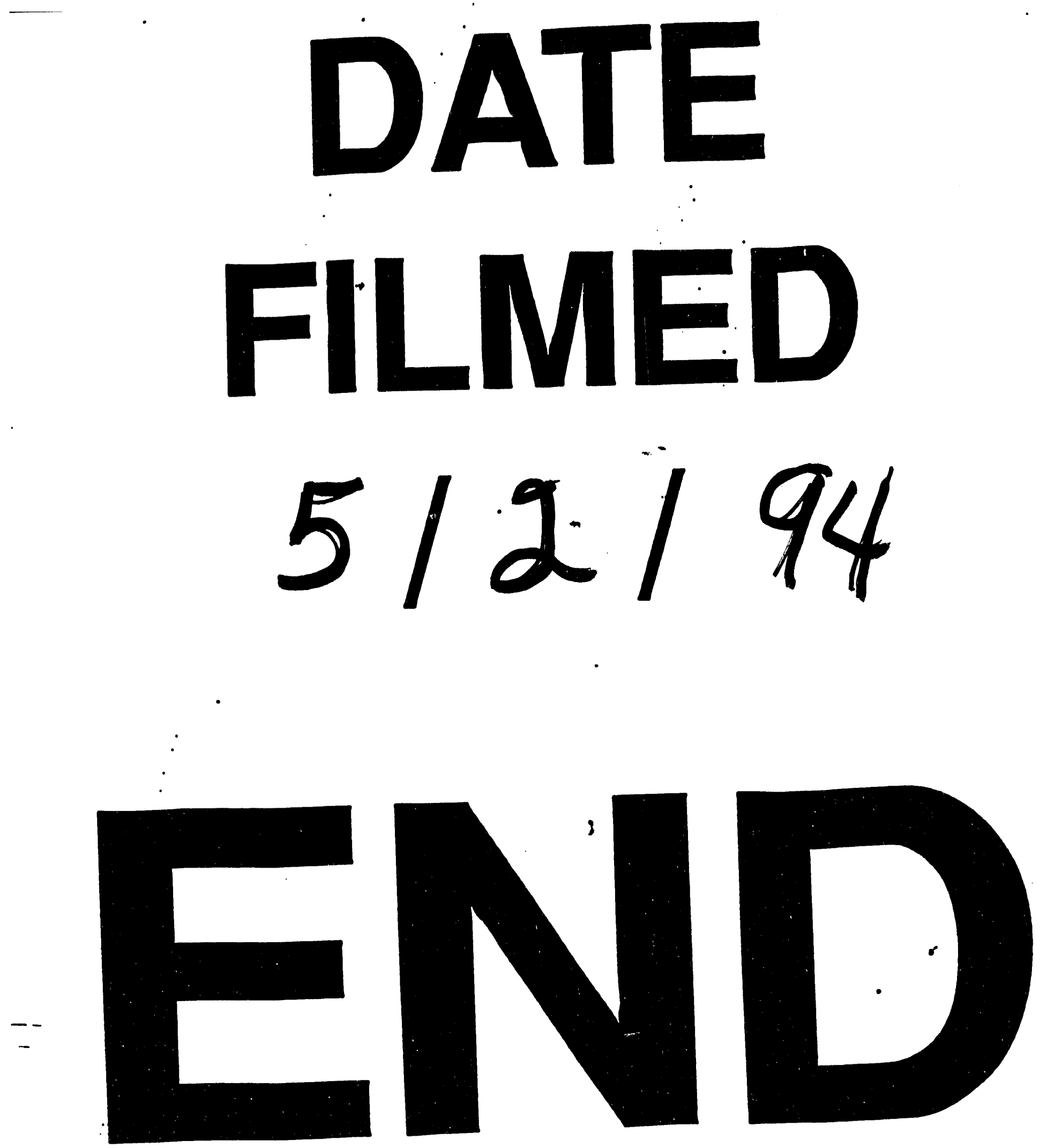


